\title{
When Good Guys Turn Bad: Bone Marrow's and Hematopoietic Stem Cells' Role in the Pathobiology of Diabetic Complications
}

\author{
Maria Cristina Vinci ${ }^{1, *, \dagger}$, Elisa Gambini ${ }^{1,+}\left(\mathbb{D}\right.$, Beatrice Bassetti ${ }^{1}$, Stefano Genovese ${ }^{2}$ and \\ Giulio Pompilio ${ }^{1}$ \\ 1 Unit of Vascular Biology and Regenerative Medicine, IRCCS Centro Cardiologico Monzino, I-20138- Milan, \\ Italy; elisa.gambini@ccfm.it (E.G.); beatrice.bassetti@ccfm.it (B.B.); giulio.pompilio@ccfm.it (G.P.) \\ 2 Unit of Diabetes, Endocrine and Metabolic Diseases, IRCCS Centro Cardiologico Monzino, \\ I-20138- Milan, Italy; stefano.genovese@ccfm.it \\ * Correspondence: cristina.vinci@ccfm.it; Tel.: +39-02-5800-2028 \\ + These authors contribution is equally to this work.
}

Received: 12 April 2020; Accepted: 27 May 2020; Published: 29 May 2020

\begin{abstract}
Diabetes strongly contributes to the development of cardiovascular disease, the leading cause of mortality and morbidity in these patients. It is widely accepted that hyperglycemia impairs hematopoietic stem/progenitor cell (HSPC) mobilization from the bone marrow (BM) by inducing stem cell niche dysfunction. Moreover, a recent study demonstrated that type 2 diabetic patients are characterized by significant depletion of circulating provascular progenitor cells and increased frequency of inflammatory cells. This unbalance, potentially responsible for the reduction of intrinsic vascular homeostatic capacity and for the establishment of a low-grade inflammatory status, suggests that bone BM-derived HSPCs are not only victims but also active perpetrators in diabetic complications. In this review, we will discuss the most recent literature on the molecular mechanisms underpinning hyperglycemia-mediated BM dysfunction and differentiation abnormality of HSPCs. Moreover, a section will be dedicated to the new glucose-lowering therapies that by specifically targeting the culprits may prevent or treat diabetic complications.
\end{abstract}

Keywords: diabetes; bone marrow; hematopoietic stem cells; inflammation; epigenetics

\section{Introduction}

Type 2 diabetes mellitus (T2DM) and also type 1 (T1DM) are associated with an increased risk of atherosclerotic cardiovascular disease (ASCVD) that represents the most prevalent cause of mortality and morbidity in diabetic patients [1,2]. Both T2DM and T1DM are characterized by hyperglycemia, and an enhanced inflammatory state that promotes and/or accelerates the molecular and cellular processes involved in the development of ASCVD in these patients [3]. The pauperization and the dysfunction induced by DM on bone marrow (BM)-derived circulating CD34 ${ }^{+}$hematopoietic stem/progenitor cells (HSPCs) are likely to play a key role in this scenario. In the last 15 years, the DM-associated dysfunctions of circulating progenitor cells have been one of the most revolutionary fields of study in diabetes. However, the preclinical and clinical data so far reported have mainly been interpreted in view of the putative cardiovascular protective and pro-angiogenic role of specific circulating progenitor subsets, overlooking the physiological function of HSPCs, which is to generate blood cell progenies in BM [4]. Only by combining all HSPC functions, which comprise both regenerative and immunological properties, we can comprehensively explain how DM-induced perturbation of these cells associates with sequelae of dramatic clinical events. Indeed, considering that HSPCs are common precursors of both pro-angiogenic and inflammatory cells, their dysfunction makes them 
both victims and perpetrators in DM and diabetic complications, respectively [5]. HSPC alterations are attributable to BM dysfunction, which is another target organ damaged by diabetic complications [6]. Speculatively, the defects of HSPCs could represent an epiphenomenon of BM impairment that become a central housekeeper of an organism's health [7]. This review deals with the modulatory effects of the diabetic milieu on BM function, providing evidence of the mechanisms involved in BM dysfunction and alteration of differentiation programs of HSPCs. Finally, a section is dedicated to the recent advances in pharmacological management of diabetes, discussing the potential protective effects of new glucose-lowering agents on BM and HSPCs.

\section{Endothelial Progenitor Cells: A Multifaceted Definition and a Unique Recognized Role in Diabetic Complications}

CD34 is a transmembrane glycoprotein that is expressed by BM-derived HSPCs [8]. HSPCs are responsible for the generation of all adult blood cells, including specialized cells that control immune function, homeostasis balance, response to microorganisms, and inflammation [9].

Since 1968, HSPC transplantation therapy has been successfully used for the treatment of various malignant human blood disorders because of their ability to reconstitute all of the hemato-lymphoid system [10]. The vast majority of HSPCs resides in specialized niches within the BM, whereas a small number of stem and progenitor cells normally traffic throughout the body. However, the mechanisms underlying this trafficking as well as the physiological significance of their migration have remained relatively obscure. The current hypothesis is that the continual egression from the $\mathrm{BM}$ niche, extravasation into different tissues, and then their re-ingression into the $\mathrm{BM}$, processes that are regulated by circadian rhythms [11], have the role of patrolling peripheral organs, with the aim of maintaining the immune responsiveness, tissue homeostasis, and regeneration. The continuous information exchange from the periphery to the BM, mediated by HSPCs and other factors, grants, beside a constant BM niche remodeling, a timely and efficient response to stressors. Indeed, different injury paradigms, such as hemorrhagic shock, inflammation, stroke, infection, and ischemia, are known to increase the circulating pool of HSPCs [12,13], even if the contribution of these cells to tissue repair and regeneration is still under investigation [14]. In 1997, Asahara and colleagues pioneered over 20 years of research in stem cell biology and regenerative medicine, which is still focused on the identification, isolation, and functional characterization of circulating BM-derived progenitors with vasculogenic properties [15]. Asahara, by identifying BM-derived circulating CD34- kinase insert domain receptor (KDR)-positive cells capable of incorporating into regenerating host vessels and contributing to vascular repair, challenged for the first time, the dogma that vasculogenesis is restricted to embryogenesis. These cells were named endothelial progenitor cells (EPCs). Since this pioneering work, nowadays, the search term "endothelial progenitor cells" in PubMed returns over 84,900 clinical, preclinical, and basic research articles, often controversial, in which these cells play the leading role (reviewed in [16-18]). The lack of consensus relies on two main reasons: The heterogeneous population of cells originated from the BM and the different methodological approaches used for their identification and characterization, such as surface marker antigens, cell culture, and clonal proliferation techniques [19-21]. So far, from a simplistic but usefulness point of view, two major EPC cell populations have been isolated by culture techniques from peripheral blood: The myeloid angiogenic cells (MACs, also called circulating angiogenic cells (CACs), pro-angiogenic hematopoietic cells (PACs) or "early EPCs") and the endothelial colony-forming cells (ECFCs or outgrowth endothelial cells or "late EPCs) [18]. Both populations, although profoundly different in surface marker antigens and functions [21], share KDR, CD31, CD34, CD105, lectin, and acetylated low-density lipoprotein (acLDL) markers (Figure 1), and are thought to synergistically cooperate in the re-vascularization processes. MACs, without changing their lineage fate and integrating into the remodeled endothelium [22,23], support endothelial repair and regeneration through paracrine factors, whereas ECFCs, an endothelial cell type characterized by potent intrinsic clonal proliferative potential, structurally contribute to de novo blood vessel formation in vivo [24,25]. Considering tissue re-vascularization as a two-steps 
proces, it has been hypothesized that MACs are first actively attracted into the damaged tissue, where, by the release of soluble factors, ECFCs are recruited, hypothetically either from the circulation or local vessel wall. Next, MACs instruct ECFC proliferation and migration to the injury site to restore the endothelial integrity of the vascular wall $[26,27]$. The ECFCs, isolated from adult human peripheral blood and cord blood, display a clonal phenotype in vitro and cell surface markers undistinguishable from non-proliferative vascular endothelial cells. This rare cell population, whose BM origin is still largely debated $[25,28,29]$, does not express progenitor cell markers and shows different functions and transcriptomic features compared with mature endothelial cells [30]. However, though ECFCs are widely accepted as putative EPCs in vitro, their effective existence and function in vivo are elusive.

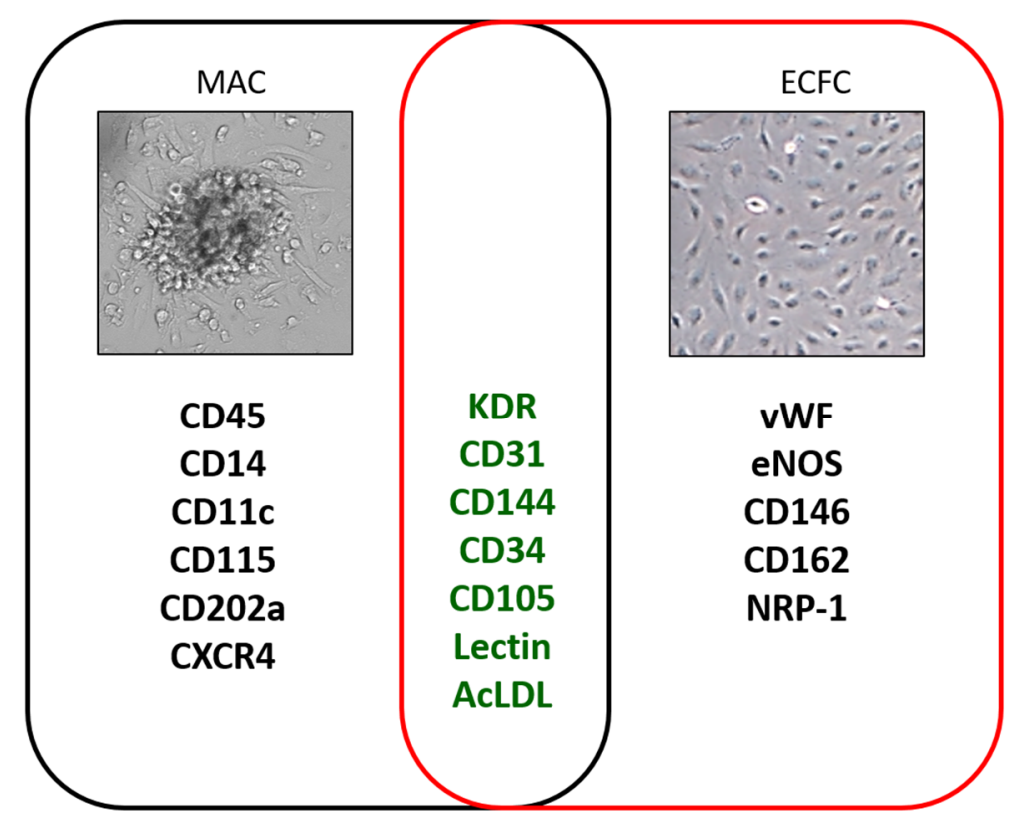

Figure 1. Cluster differentiation (CD) and other markers that identify myeloid angiogenic cells (MACs), black left circle, and endothelial colony forming cells (ECFCs), red right circle. The markers shared by both cell populations are in the center. Cluster domain (CD); CXC motif, receptor 4 (CXCR4); kinase insert domain receptor (KDR); acetylated low-density lipoprotein (acLDL); Von Willebrand factor (vWF); endothelial nitric oxide synthase (eNOS); Neuropilin-1 (NRP-1).

\subsection{Circulating HSPCs: Current Concept and Implication in Health and Disease}

Despite the 20 years of research efforts dedicated to the identification of EPCs, the impossibility of sharply separating EPCs from hematopoietic cells, either progenitor or myeloid lineage-committed, is so far evident because of their overlapping phenotypes [31,32]. Today, many research groups are now inclined to identify circulating EPCs with the more generic $\mathrm{CD} 34^{+} / \mathrm{CD} 133^{+} \mathrm{HSPC}$ population because it is the ancestor of all EPC phenotypes. The qualitative and quantitative depletion of circulating HSPCs, which encompasses progenitor subsets with multiple lineage commitment, has been shown to be independently associated with the risk of mortality in patients with coronary artery disease [33], renal disease [34], as well as with the severity of pathologies, such as Alzheimer's [35] and cognitive impairment [36]. Such epidemiological observations derived from different cohorts of patients clearly suggest an important role of circulating HSPCs in the physiological mechanisms of endogenous tissue regeneration. This hypothesis is further supported by numerous preclinical and clinical studies showing the ability of these cells to repopulate non-hematopoietic tissues, including the kidney, heart, and lungs [37-41], as well as their efficacy, although controversial regarding the exact definition and function of such cells, in the treatment of cardiovascular disease, peripheral arterial disease, and critical limb ischemia in humans [42-44]. 


\subsection{Circulating HSPCs and Diabetes: A Strong and Intertwined Relationship}

Following EPCs' identification, HSPCs are now considered integral components of the mechanisms involved in the maintenance of endothelial integrity, vascular homeostasis, and endogenous tissue regeneration in general. DM induces micro- and macro-angiopathies that over time lead to long-term damage and failure of various organ and systems. So far, numerous molecular mechanisms and pathways have been described to translate hyperglycemia, the hallmark of DM, into tissue damage [45]. However, dramatically, the same mechanisms seem to also be involved in impairment of the endogenous vascular reparative system, including stem cells. Considering that cell turnover is essential to face the physiological rate of cell senescence and death, it is easy to predict that in the subjects in whom intrinsic repair processes are defective, tissue damage can worsen. Under this prospective, the DM has been considered a disease of impaired damage control [46], which would explain the two- to three-fold increase of cardiovascular risk in this patient category. The discovery that diabetes affects stem/progenitor cell biology opened an important research field in diabetology, where stem cell dysfunction is at the center of the pathophysiological mechanisms of diabetic complications [47]. A consistent body of studies has documented the reduction and dysfunction in T2DM and T1DM of pro-angiogenic HSPCs (at the time still termed EPCs) [48-52]. These alterations, interpreted in view of a regenerative role, have been mechanistically considered to contribute to the onset and progression of vascular disease [53]. Importantly, a careful analysis of the same clinical studies reveals that pro-angiogenic HSPC alterations follow the natural history of diabetes, from its development to the later stage. This peculiarity suggests that the reduction of circulating pro-angiogenic HSPC numbers may also represent a biomarker of adverse cardiovascular events. Consistently, reduced levels of circulating pro-angiogenic HSPCs (EPCs) have already been associated with endothelial dysfunction, cardiovascular events, and with the pathogenesis of stroke in different cohorts of patients [54-57]. A recent meta-analysis by Rigato et al. showed that the numerical pauperization of circulating progenitors, in particular $\mathrm{CD} 34^{+} / \mathrm{CD} 133^{+} \mathrm{HSPC}$, was associated with a 2-fold increased risk of future cardiovascular events and cardiovascular death in patients with suspected coronary artery disease, acute coronary syndrome, previous stroke, or in patients without acute events but with cardiovascular risk factors [58]. To note, the reduction of the same circulating cell population has recently been proven to be an efficient clinical-grade-independent biomarker in macro- and microvascular disease, capable of predicting long-term adverse cardiovascular outcomes in T2DM patients $[59,60]$. Though the molecular mechanisms mediating numerical and functional alteration of $\mathrm{CD} 34^{+} / \mathrm{CD} 133^{+} \mathrm{HSPC}$ in diabetes are still largely obscure (reviewed in [61]), BM is emerging as the original core of HSPC dysfunction.

To better clarify the mechanisms underpinning diabetic BM dysfunction, it is appropriate to introduce the complex cellular and molecular network regulating HSPC niche function.

\section{Healthy BM}

$\mathrm{BM}$ is the major hematopoietic organ and lymphoid tissue responsible for the production of erythrocytes, granulocytes, monocytes, lymphocytes, and platelets; moreover, it also represents the largest reserve of HSPCs in an adult organism [62]. Within the BM, HSPCs reside in a specialized microenvironment called the niche [63]. The BM niche, defined for the first time by Richard Shofield in 1978 [64], is an anatomical compartment composed by stromal cells, mesenchymal cells, osteoblasts, endothelial cells, reticular cells, and the extracellular matrix. The continuous molecular crosstalk between HSPCs and the other niche cellular constituents regulates HSC migration, quiescence, and differentiation $[63,65,66]$.

So far, two distinct niches have been identified: Endosteal niche, lining the bone surface, and the vascular niche located around the sinusoidal endothelium. The two compartments are not separated but dynamically regulated and interrelated. Endosteal HSPCs are thought to mature during their relocation to the vascular niche; however, it is still unclear if endosteal and vascular HSPCs are mutually exchangeable [62]. The HSPC localization within the niches tightly correlates with the proliferative and maturation status of the cells. Indeed, HSPCs characterized by a high self-renewal capacity are localized 
near the endosteum, and as they mature, they move towards vascular sinusoids (vascular niche) [63,67], which play a pivotal role in progenitor cell egression from the BM to the circulation [68]. Osteoblasts of the endostal niche, which is further composed of a heterogeneous cell population, including fibroblasts and endothelial cells, regulate HSPC proliferation and quiescence [69]. There is evidence that osteoblast lineage cells are required to maintain the 'endosteal stem cell niche' as their expansion by genetic or pharmacologic means results in a concurrent expansion of HSPCs, whereas their ablation leads to HSPC loss [70]. In addition, osteoblasts also play a key role in HSPCs' mobilization because they are a source of stromal cell-derived factor 1 (SDF-1/CXCL12 (CXC motif, ligand 12)), even if the interaction of this chemokine with its cognate receptor, CXCR4 (CXC motif, receptor 4) is not the only mechanism regulating HSPC trafficking in the BM. In this regard, numerous studies reported a very complex picture of the mechanisms regulating the homeostasis and mobilization of HSPCs that comprise not only endothelial cells and mesenchymal stromal progenitor cells but also mature hematopoietic neutrophils and macrophages. A recent review detailed the role that each of these cells of the HSPC niche play in contributing to mobilization [71]. Osteoblasts are also able to regulate HSPC survival, quiescence, and differentiation by producing factors, such as angiopoietin-1 [72] and thrombopoietin, capable of directly binding the HSPCs [73]. Stromal cells, on the other hand, are able to retain the HSPC in the BM by interacting between the vascular cell adhesion molecule 1 (VCAM-1) to the very late antigen-4 (VLA-4) antigen present on the HSPCs [74]. The maturation of the HSPCs is regulated by the Notch signal through interaction with osteoblasts [75].

The arterial vessels enter into the BM through the foramina nutricia and then divide into arterioles, capillaries, and sinusoids. Sinusoids, where the vascular niche is localized, consist of fenestrated endothelium and, to a lesser extent, pericytes, forming a permeable barrier for HSPC passage into the circulation [76]. While HSPCs located at the endosteum are more quiescent and have a greater self-renewal capacity due to a variety of cytokines, adhesion molecules, and hypoxia, HSPCs located close to the sinusoid endothelium (vascular niche) have reduced self-renewal capacity and cycle more rapidly due to higher oxygen levels. The cells of the vascular niche communicate with cells of the endosteal niche, and the subtle balance of factors from these sub-compartments governs the behavior of the HSPCs [77]. The vascular niche is involved in the proliferation and differentiation of HSPCs thanks to the presence of hormones, growth factors, oxygen, and nutrients from the peripheral circulation $[78,79]$. Moreover, the presence of different cell types, such as endothelial cells, mesenchymal cells, perivascular stromal cells (e.g., CXCL12-abundant reticular-CAR ${ }^{+}$, nestin ${ }^{+}$, and leptin ${ }^{+}$receptor-Lepr+ cells), and Schwann cells [80-82], associated with HSPCs grant a fine-tuned regulation of stem cell quiescence and maintenance [83,84].

Overall, both endosteal and vascular niches support hematopoiesis and mobilization through paracrine signaling and physical interactions. Moreover, BM vascular cells direct the regular trafficking of HSPCs to the systemic circulation and back to the BM. Importantly, both niches are highly innervated [67]. Indeed, both niches are also finely regulated at the neuronal level by the sympathetic nervous system (SNS), which acts on perivascular cells through $\beta 3$-adrenergic receptors. These signals that regulate CXCL12 expression in BM stromal cells allow HSPCs' mobilization through circadian rhythms [85]. For example, nestin ${ }^{+}$cells expressing the beta-adrenergic receptors, following noradrenergic stimuli, are able to downregulate the retention signals, allowing HSPC mobilization [78]. Similarly, granulocyte colony stimulating factor (G-CSF)-mediated HSPC mobilization is the result of SNS signaling on perivascular cells [86]. The SNS also acts directly on the HSPCs by the binding of adrenergic neurotransmitters (epinephrine and norepinephrine) and dopamine on $\beta 2$-adrenergic receptors of HSPCs, which act as chemoattractants [87].

In homeostatic conditions, the number of HSPCs that physiologically leave the BM niche and reach the peripheral organs through the circulation to maintain tissue integrity is low. However, this number rapidly increases following tissue injury [62]. The mobilization of HSPC from the BM after injury is a delicate process that involves not only chemokine gradients and SNS activation [88,89] but also mediators, such as matrix metalloproteinases type 2 and 9; cathepsin $\mathrm{K}$, which is secreted by 
osteoclasts; and elastases, produced by neutrophils [90]; all these proteases have the task of cutting the interactions between HSPCs and their niche microenvironment [62].

\section{Diabetic BM}

BM is now recognized as a target organ for chronic diabetic complications, in which defects, such as mobilopathy, neuropathy, and microangiopathy, are the main pathologic manifestations [76]. Profound alterations in gene expression and cytokine signaling induced by the diabetic microenvironment are the basis of changes in the BM cellular component, such as increased adipogenesis and decreased osteoblastogenesis [91].

Preclinical and clinical studies have implicated reactive oxygen species (ROS) overproduction, endoplasmic reticulum stress alterations, and advanced glycation end products (AGEs) in the abrogation of proangiogenic pathways involved in the restoration of perfusion and regeneration of ischemic tissue in DM. To these should also be added, for the sake of completeness, the marked impairment of BM-derived HSPC mobilization, recruitment, and pro-angiogenic differentiation [50,90,92-95]. These defects could depend on (i) reduced cell survival in the circulatory stream, (ii) altered homing out of the vessels, (iii) BM dysfunction with insufficient and less viable stem cell release, or (iv) a combination of all [7].

\subsection{Mobilopathy}

Mobilopathy is defined as the inefficient release of HSPCs from BM due to an altered gradient of chemokines both within the BM and between the BM and the periphery [67]. This functional defect can be partly explained by CXCL12/CXCR4 axis dysregulation [96]. Under homeostatic conditions, both the stem cell factor (SCF (also referred as KIT-ligand)/c-Kit (CD117) axis, and the binding between CXCL12, mainly produced by BM stromal cells, and CXCR4/CXCR7 receptors expressed on HSPCs keep the cells anchored to the niche. In response to peripheral ischemia, the decline of BM CXCL12 levels is the key signal of HSPC mobilization. In diabetes, however, CXCL12 in the BM does not decrease following ischemia, leading to an inefficient mobilization of HSPCs [97]. In this regard, Albiero and co-workers found an excess of proinflammatory M1 macrophages in the BM of a T1DM mice model. Moreover, they also found that oncostatin M (OSM) was the long-sought soluble factor released by macrophages that sustained CXCL12 expression by mesenchymal stem/stromal cells, which was no longer downregulated even after G-CSF stimulation. A few years later, the same authors also demonstrated that the oncostatin M (OSM)-p66Shc pathway mechanistically linked HSPC mobilopathy to excessive myelopoiesis [98,99].

In the ischemic tissue, the transcription factor hypoxia-inducible factor-1 (HIF-1) regulates CXCL12 gene expression in endothelial cells, which is directly proportional to reduced oxygen tension. HIF-1-induced CXCL12 expression increases the adhesion, migration, and homing of circulating CXCR4-positive progenitor cells to the ischemic site [100]. Diabetes is known to upregulate dipeptidyl peptidase-4 (DDP-4) expression, an enzyme involved in CXCL12 degradation, in the peripheral tissue. This DDP4-dependent reduction of CXCL12 levels results in the dampening of HSPC recruitment with a consequent angiogenesis deficit, as demonstrated in the heart of rats with chronic heart failure [101]. In the BM, on the other hand, DM inadequately upregulates DPP- 4 on CD $34^{+}$cells, which is required for the mobilizing effect of G-CSF [102]. Nevertheless, DDP-4 inhibition was shown to promote HSPC mobilization by protecting CXCL12 from inactivation [103] and enzymatic degradation [104] in T2DM patients.

In addition, endothelial nitric oxide synthase/nitric oxide (eNOS/NO) pathway activation, fundamental for HSPC mobilization, is also compromised in diabetes, as demonstrated in a murine model of diabetes, where the eNOS enzyme was decoupled [105] and its phosphorylation rate reduced [106]. 


\subsection{Inflammation}

The increase of proinflammatory cytokines, such as interleukin-3 (IL-3), IL-10, IL-1 $\beta$, tumor necrosis factor- $\alpha$ (TNF- $\alpha$ ), and monocyte generation has been observed in the BM of a T1DM mice model [107]. Moreover, the downregulation of insulin-like growth factor 1, insulin-like growth factor-binding protein 5, osteoprotegerin, and vascular endothelial growth factor (VEGF) $n$ the BM plasma of T1DM mice was associated with reduced Bmilexpression, a gene involved in senescence protection, and with an impaired HSPC repopulation of BM [108]. Hyperglycemia is also able to induce a small but specific BM cell subpopulation, identified by proinsulin production, that expresses TNF- $\alpha$, a cytokine implicated in numerous diabetic complications, including diabetic peripheral neuropathy (DPN) [109]. This latter finding represents the first emerging evidence of active HSPC contribution to the pathogenesis of DPN.

\subsection{Neuropathy}

Sensory neuropathy is a common complication of DM characterized by damage of the sensory nerves. This causes an altered pain perception and impairs the activation of healing mechanisms after injury. Under physiological conditions, peripheral sensory neurons release, after damage, nociceptive factors, such as substance P (SP), which exert local and systemic actions, including recruitment to the site of damage of BM and circulating HSPCs expressing the neurokinin 1 receptor (NK1R), the main SP receptor. Recent studies demonstrated that sensory neuropathy can occur in the bone marrow of T2DM patients and mice. The rarefaction of nociceptive fibers in the diabetic BM was associated with an impairment in the neurokinin gradient between the BM, peripheral blood, and peripheral tissue, accompanied by a depressed recruitment of NK1R-HSPCs to the site of injury [110,111].

It is known that SNS is prominently involved in BM niche function [88] and stem cell trafficking is regulated by catecholaminergic neurotransmitters [87]; therefore, diabetic autonomic neuropathy (DAN) may also impact the BM. Albiero et al. demonstrated that BM denervation in an experimental model of diabetes (streptozotocin-induced and ob/ob mice) was mediated by p66Shc upregulation and that impaired mobilization relied on sirtuin 1 (Sirt1) dysregulation [112]. In this complex scenario, Lucas et al. showed that G-CSF is able to directly increase the sympathetic tone. Peripheral sympathetic nerve neurons express the G-CSF receptor and its stimulation with G-CSF reduced norepinephrine reuptake significantly, suggesting that G-CSF potentiates the sympathetic tone by increasing the norepinephrine availability. Their data suggest that the blockade of norepinephrine reuptake may be a novel therapeutic target to increase the stem cell yield in DAN patients [113]. Using a rat model of T2DM, Busik et al. demonstrated that BM neuropathy preceded the development of diabetic complications. They observed a reduced number of nerve endings in the BM of diabetic rats that coincided with a numerical increase of pro-angiogenic HSPCs within the BM and decrease of their circulating levels. In addition, denervation was also accompanied by a loss of HSPC circadian release, suggesting that inherent sympathetic denervation can alter the circadian peripheral clock. Overall, both DM-induced denervation and circadian clock impairment led to diminished reparative capacity, eventually resulting in the development of diabetic retinopathy [114].

\subsection{Microangiopathy}

Diabetes induces microvascular remodeling with a negative consequence for BM homeostasis. Oikawa et al. demonstrated that cultured endothelial cells from the BM of T1DM mice showed increased levels of oxidative stress, senescence, reduced migratory and network formation capacities, and increased permeability. BM endothelial cell dysfunction, in which numerous mechanisms, including increased expression and activity of Ras homolog family member A (RhoA) and reduced Akt phosphorylation/activity, are involved, is responsible for reduced BM perfusion and consequent HSPC loss. In addition, HSPC depletion induced by BM microangiopathy was associated with increased oxidative stress, DNA damage, and apoptosis of the stem cells $[6,115]$. 


\subsection{Oxidative Stress}

The reactive oxygen species (ROS) gradient is a fundamental signaling mechanism controlling functional niche compartmentalization of stem cells in the BM. The precious low replicating HSPCs, necessary for BM repopulation, reside in the "low ROS zones", ideal for the maintenance of quiescence and retention, whereas the "high ROS zone" adjacent to the marrow vasculature has the function of facilitating stem cell maturation [6]. However, under pathologic conditions, such as diabetes, excessive ROS production [116] might jeopardize stem cell viability by promoting DNA damage and senescence [6,62]. Numerous mechanisms might account for increased oxidative stress in HSPCs, including BM hypoperfusion and hyperglycemia, both recognized as strong inducers of ROS generation by mitochondrial complex III, and exposure to ROS produced by other cell sources, such as endothelial and stromal cells of the niche $[6,117,118]$. In this context, Src homology/collagen (Shc) adaptor protein 66 (p66Shc), a gene that regulates the apoptotic responses to oxidative stress, plays a fundamental role. Di Stefano et al. showed that in vitro hyperglycemia-induced upregulation of p66Shc protein in HSPCs derived from mouse BM correlated with increased mitochondrial ROS production and a marked reduction of pro-angiogenic commitment of the cells. Conversely, p66Shc knockout BM-derived HSPCs were insensitive to high glucose exposure. Importantly, the high glucose resistance of p66Shc knockout BM-derived HSPCs was prevented by nitric oxide (NO) synthase inhibition, suggesting that the reduction of NO bioavailability induced by ROS was the underlying mechanism involved in pro-angiogenic HSPC dysfunction [119].

\section{Evidence of Diabetes-Induced HSPC Programming and Pathobiological Implications}

The BM harbors immature progenitor cell populations characterized by high plasticity and multiple cell lineages' commitment, not limited to the hematopoietic system [120,121]. As previously reported, the stem cell niche has an important role in HSPC homeostasis [122,123]. This suggests that BM niche alterations induced by the diabetic milieu might have profound implications in HSPC biology, for example, by redirecting differentiation toward harmful cell populations that rather than protecting, promote the progression of diabetic complications. In this regard, numerous studies have reported the existence of BM-derived circulating progenitors with smooth muscle (smooth muscle progenitors, SMPs) $[124,125]$ and calcifying phenotypes (osteoprogenitor cells, OPCs) [126,127], in DM patients. These cells, hypothetical "side products" of differentiation drift, witness the fact that diabetes not only reduces the number of vasculoprotective cells but also promotes the generation of cells with anti-angiogenic [128] and pro-fibrotic properties [129], with clear implications in diabetic micro- and macro-angiopathies' development. In addition to mobilization defects of pro-angiogenic HSPCs and generation of aberrant progenitor cell populations, DM patients tend to have an elevation of peripheral inflammatory monocytes [130-132], an alteration in macrophage polarization [133], as well as increased levels of circulating inflammatory cytokines [134]. Terenzi and colleagues recently demonstrated the incontrovertible reduction of circulating proangiogenic progenitors and the increased frequency of circulating proinflammatory cells in TD2M patients [135]. Cumulatively, this unbalance, which culminates in a reduction of the intrinsic vascular homeostatic capacity and in the establishment of a low-grade inflammatory status [136], might be the main driver in atherosclerosis development and the increased risk of CVD in DM patients [137,138]. Loomans et al. for the first time hypothesized that hyperglycemia could modulate HSPC function. He demonstrated that hyperglycemia altered the differentiation fate of $\mathrm{BM}$ precursor cells, reducing the potential to generate vascular regenerative cells and favoring the development of proinflammatory cells [139]. After this publication, other studies based on the murine model of diabetes further substantiated and mechanistically detailed this finding $[107,140,141]$.

Recent evidence supports the concept that epigenetic mechanisms may participate in the differentiation drift of HSPCs into more inflammatory cell populations within the BM. Epigenetic modifications have been documented in inflammation [142], and diabetic conditions are known to elicit epigenetic changes in a variety of cell types, including HSPCs $[143,144]$. In this regard, we recently 
demonstrated that a hyperglycemic condition induced inhibitory histone modifications and DNA methylation of the CXCR4 promoter in cord blood-derived CD $34^{+}$stem cells. These epigenetic alterations, also identified in BM-derived $\mathrm{CD} 34^{+}$stem cells of T2DM patients, were associated with a functional impairment of the CXCR4/CXCL12 axis [145]. This study, which demonstrates a direct impact of hyperglycemia exposure on the epigenetic make-up of stem cell promoters, further supports the hypothesis that epigenetic changes are likely additional mechanisms by which diabetes promotes the generation of inflammatory BM-derived monocytes and macrophages in diabetic patients, contributing to enhanced CVD. In a mouse model of insulin resistance, Gallagher and colleagues found that a repressive histone methylation mark, $\mathrm{H} 3 \mathrm{~K} 27 \mathrm{me} 3$, is decreased at the promoter of the IL-12 gene in $\mathrm{BM}$ progenitors and this epigenetic signature is passed down to macrophages [146]. Similar findings, even if in different genes and experimental settings, have been described by other authors [147,148]. In particular, Yan et al. observed in T2DM mice DNA methyltransferase 1 (DNMT1)-dependent dysregulation of genes related to macrophage differentiation in HSPCs that was carried down through progenitor cells to terminally differentiated cells [148]. This study supports the concept that the gene expression pattern of terminally differentiated immune cells might be epigenetically "preprogrammed" by hyperglycemia at the HSPC level and may potentially be responsible for the prolonged and intrinsic inflammatory status of diabetics [138] (Figure 2).

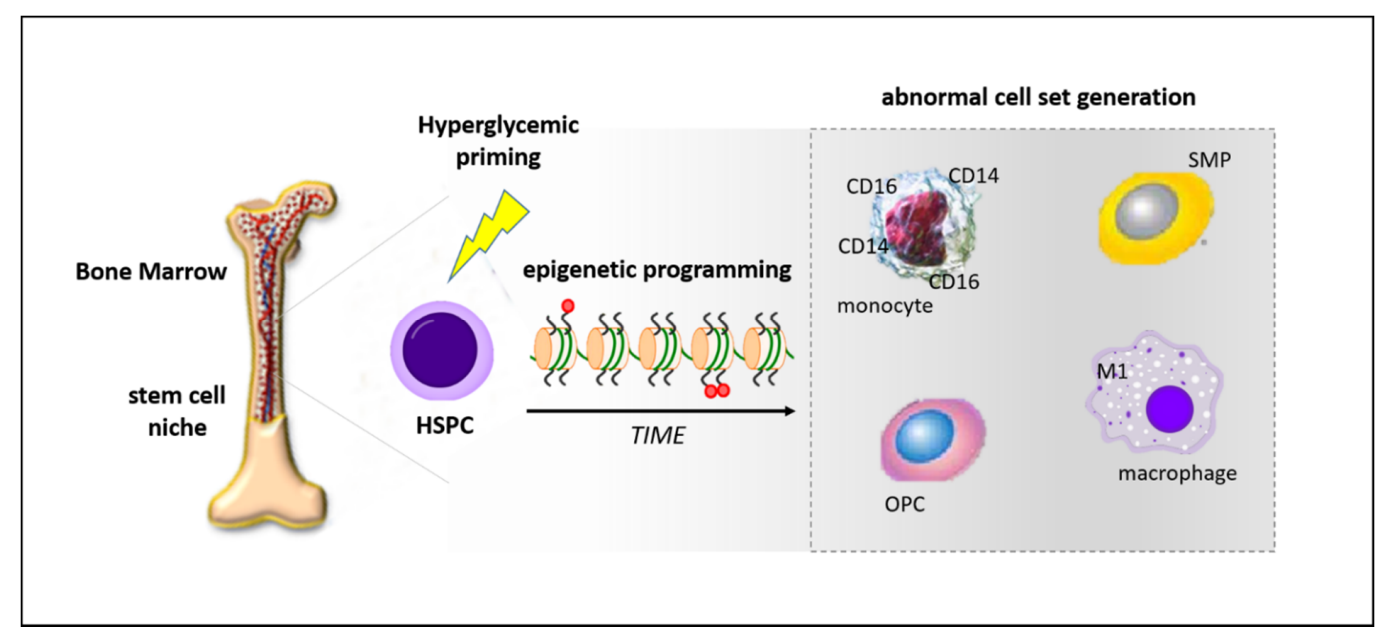

Figure 2. Schematic representation of hyperglycemia-induced programming of hematopoietc stem progenitor cells (HSPCs) at the bone marrow level. Diabetic milieu promotes epigenetic changes in HSPCs that result in the abnormal expansion of cells with inflammatory and pro-atherosclerotic features, such as intermediate monocytes (CD14+CD16+), M1 macrophages, osteoprogenitor cells (OPCs), and smooth muscle progenitors (SMPs).

Thus, epigenetic changes can be considered causative factors contributing to the differentiation drift of HSPCs in DM. Whether this alteration in DM is potentially reversible is not fully clear; however, there is growing body of evidence regarding the use of epigenetic drugs to restore/improve HSPC function. Multiple studies have reported that chemical modifiers of DNA demethylation, such as 5-azacytidine, or histone deaacetylase inhibitors, such as trichostatin A, valproic acid, or methyltransferase EZH2 inhibitors, enzymes that establish repressive H3K27me3 marks, have been shown to not only enhance both the plasticity and function of progenitor cells but also change the cell fate by chromatin remodeling $[149,150]$. Interestingly, the inhibition of bromodomain and extraterminal domain (BET) proteins by the food drug administration (FDA)-approved drug apabetalone (RVX-208) has been shown to modulate coagulation, vascular inflammation [151,152], and innate/adaptive immune responses, suggesting its potential use in the epigenetic treatment of chronic diabetic inflammation and vascular complications [153]. 


\section{The Protective Role of Glucose-Lowering Drugs on the HSPC Level and Inflammatory Profile}

Patients with T2DM are at high risk of developing ASCVD, the leading cause of morbidity and mortality in these patients [154]. Recent guidelines indicate that people with T2DM and established ASCVD, besides adequate glucose control, should be managed with glucose-lowering drugs proven to reduce major adverse cardiovascular events and/or cardiovascular mortality $([155,156]$, http://www.siditalia.it/clinica/standard-di-cura-amd-sid). Nevertheless, the mechanisms by which these drugs exert pleiotropic cardiovascular effects are not completely understood.

It is well known that HSPC dysfunction and systemic chronic inflammation are very common features in T2DM patients, and some reports have already shown that metformin can partially reverse these processes [157,158]. Accordingly, a number of studies have been performed (or are still ongoing) to evaluate whether therapeutic approaches with other glucose-lowering drugs, including peroxisome proliferator-activated receptor gamma (PPAR- $\gamma$ ) agonists, dipeptidyl peptidase 4 (DPP-4) inhibitors, glucagon-like peptide 1 (GLP-1) receptor agonists, and sodium-glucose transport protein 2 (SGLT2) inhibitors, may reduce or reverse these pathophysiologic factors in T2DM patients.

PPAR- $\gamma$ agonists, also known as thiazolidinediones, were the first investigated. Several randomized and non-randomized clinical trials using PPAR- $\gamma$ agonists in T2DM patients have shown positive results in terms of the endothelial function and inflammatory profile [159-164]. As an example, the largest randomized clinical trial by Esposito et al. [162], cumulatively enrolling 110 newly diagnosed T2DM patients, proved the superiority of pioglitazone versus metformin in improving the imbalance between endothelial damage (i.e., the endothelial microparticles expressing CD31) and the endothelial repair capacity (i.e., the endothelial progenitors expressing CD34/KDR). As for inflammation and oxidative stress, in a study on T2DM patients naïve to therapy, pioglitazone after 16 weeks significantly reduced CRP and E-selectin levels from baseline and in comparison to metformin, whereas no difference was observed for nitrotyrosine (a marker of oxidative stress) between the two treatments [165]. Interestingly, a prospective randomized controlled study that compared pioglitazone and rosiglitazone with the best standard of care showed that both treatments significantly decrease serum VEGF levels compared to controls $(p=0.00)$ and reduced thee serum TNF- $\alpha$ concentration, with a statistical significance for the pioglitazone group only $(p=0.01)$ [166]. Cumulatively, these results provide solid evidence for the anti-inflammatory and cardioprotective effect of PPAR- $\gamma$ therapy and pioglitazone, which so far represents a valid therapeutic strategy in T2DM patients with established ASCVD ([155], http://www.siditalia.it/clinica/standard-di-cura-amd-sid).

As for DPP-4 inhibitors, sitagliptin and saxagliptin are the most widely investigated along with vildagliptin in this setting $[104,167,168]$. However, results are mixed. For example, the EDGE study (Effectiveness of Diabetes control with vildaGliptin and vildagliptin/mEtformin) revealed that 12 weeks of sitagliptin treatment increased circulating CD34 ${ }^{+}$cells $(p=0.03)$ but did not change inflammatory markers (i.e., high-sensitivity CRP and pentraxin-3) and oxidative stress markers (i.e., malondialdehyde-modified low-density lipoprotein and urine 8-hydroxy-2'-deoxyguanosine) [169]. Other investigators observed similar biological effects with saxagliptin for 12 weeks and vildagliptin for 12 months, respectively $[167,168]$. Conversely, other investigators did not find differences regarding both EPC functionality and the inflammatory profile in patients treated with different DPP-4 inhibitors [170-173]. In addition, a very recent network meta-analysis demonstrated the superiority of SGLT-2 inhibitors and GLP-1 agonists versus DPP-4 inhibitors in preventing cardiovascular events and mortality in this setting of patients [174].

Likewise, GLP-1 receptor agonists have been proposed for their protective role on vascular endothelium and the immune system [175-177]. Wei et al. [176] enrolled 31 newly diagnosed T2DM patients receiving lifestyle modifications plus incremental doses of exenatide $(10 \mu \mathrm{g} /$ day for 1 month and $20 \mu \mathrm{g} /$ day for 2 months) or lifestyle modifications alone. This study showed that exenatide treatment significantly improved the endothelial function of coronary arteries by measuring the coronary flow velocity reserve (CFVR) and the system inflammation status by reducing the circulating levels of vascular adhesion molecules (i.e., soluble intercellular and vascular adhesion molecule-1). 
Similar results were also reported in other head-to-head comparison studies. For example, it was shown that exenatide and metformin treatments can equally improve endothelial dysfunction and inflammation [178], even in a pre-diabetes setting [179].

However, it is worth noting that overall, these trials did not adopt a placebo-controlled group. In addition to exenatide, the impact of liraglutide in T2DM patients is under investigation $[180,181]$ but available data are still limited. A parallel-group study of liraglutide and glargine therapy showed a reduced deterioration of endothelial function for the group receiving liraglutide compared with controls as measured by flow-mediated dilation. However, this difference was not significant $(5.7 \%$ to $5.4 \%$ and $6.7 \%$ to $5.7 \%$, respectively) [181]. In a recent prospective randomized open-label trial, the administration of liraglutide and dulaglutide for 24 weeks produced the same antioxidant effect as demonstrated by improvements in the diacron-reactive oxygen metabolite and reactive hyperemia index [180]. However, this was an open-label study with a small sample size $(n=22)$. More definitive indications will arise from the ongoing clinical trials testing the role of semaglutide (NCT04126603) and liraglutide (NCT02686177) in regulating vascular integrity and angiogenesis.

More recently, investigators have focused on the novel drug class of SGLT-2 inhibitors [182,183]. Specifically, in the DEFENCE trial (dapagliflozin effectiveness on vascular endothelial function and glycemic control), Shigiyama et al. [184] compared the effect of dapaglifozin plus metformin and metformin alone in 80 early stage T2DM patients. At the end of the 16-week treatment period, the authors showed that the dapaglifozin add-on therapy compared to metformin-alone therapy significantly improves the flow-mediated dilation in those patients having $\mathrm{HbA} 1 \mathrm{c} \geq 7.0 \%$ at baseline $(1.05 \pm 2.59$ versus $-0.94 \pm 2.39 ; p<0.05)$ and reduces urine 8-hydroxy-2'-deoxyguanosin, a clinical marker of oxidative stress $(-0.6 \pm 1.8$ versus $1.1 \pm 2.2 ; p<0.001)$. In contrast, the EMBLEM trial (Effect of Empagliflozin on Endothelial Function in Cardiovascular High Risk Diabetes Mellitus) [185], in which a total of 117 adults with T2DM and established ASCVD were randomized to receive either empagliflozin $10 \mathrm{mg}$ daily or placebo for 24 weeks, did not find differences in the primary endpoint (i.e., the change in the reactive hyperemia peripheral arterial tonometry index). Further insights will emerge from the ongoing randomized parallel-group trials. For example, the "Role of Canagliflozin on CD34 ${ }^{+}$Cells in Patients With Type 2 Diabetes" trial (NCT02964585) is currently recruiting patients with T2DM to study, as the primary endpoint, the gene expression and functional changes of CD34 $4^{+}$ EPC. Other secondary endpoints, including serum endothelial inflammatory markers (hs-CRP, IL-6, and TNF-alpha), will also be investigated.

Interestingly, clinical trials are ongoing, and aim to evaluate the combination of glucose-lowering drugs possessing complementary and synergistic effects, such as saxagliptin plus dapaglifozin (NCT03660683) or empagliflozin plus liraglutide (NCT03878706).

\section{Concluding Remarks}

It is now clear that the BM is a target organ for chronic diabetic complications and HSPCs play an active role in the development of multiple organ vascular complications. The realization that DM may not only impair HSPC mobilization from the BM but also program the differentiation towards progenitors with defective vasculotrophic functions and excessive proinflammatory, pro-calcific, and fibrotic properties, with direct effects in the pathogenesis of diabetic complications, opens a new and exciting chapter of investigation in the diabetes field. From a therapeutic standpoint, the achievement of good glycemic control without glucose variability remains the best and primary way of preventing diabetic complications. However, a better understanding of the cellular and epigenetic mechanisms involved, as inciting events, in the differentiation drift of BM stem/progenitor cells towards deleterious cell populations in diabetes will help to identify new treatments to slow down or reverse diabetic complications. 
Author Contributions: M.C.V.: Literature review, collection, conception, design and manuscript writing, final approval of the manuscript. E.G.: Literature review collection and assembly of data, manuscript writing. B.B.: collection and assembly of data, manuscript writing. S.G.: manuscript editing. G.P.: manuscript editing. All authors have read and agreed to the published version of the manuscript.

Funding: This study was supported by Italian Ministry of Health, Ricerca Corrente (RC 2019).

Conflicts of Interest: The authors declare no conflict of interest.

\section{References}

1. De Matheus, A.S.M.; Tannus, L.R.M.; Cobas, R.A.; Palma, C.C.S.; Negrato, C.A.; de Gomes, M.B. Impact of diabetes on cardiovascular disease: An update. Int. J. Hypertens. 2013, 2013, 653789. [CrossRef] [PubMed]

2. Miller, R.G.; Mahajan, H.D.; Costacou, T.; Sekikawa, A.; Anderson, S.J.; Orchard, T.J. A Contemporary Estimate of Total Mortality and Cardiovascular Disease Risk in Young Adults With Type 1 Diabetes: The Pittsburgh Epidemiology of Diabetes Complications Study. Diabetes Care 2016, 39, 2296-2303. [CrossRef] [PubMed]

3. Kanter, J.E.; Bornfeldt, K.E. Inflammation and diabetes-accelerated atherosclerosis: Myeloid cell mediators. Trends Endocrinol. Metab. 2013, 24, 137-144. [CrossRef] [PubMed]

4. Patel, J.; Donovan, P.; Khosrotehrani, K. Concise Review: Functional Definition of Endothelial Progenitor Cells: A Molecular Perspective. Stem Cells Transl. Med. 2016, 5, 1302-1306. [CrossRef] [PubMed]

5. Kojima, H.; Kim, J.; Chan, L. Emerging roles of hematopoietic cells in the pathobiology of diabetic complications. Trends Endocrinol. Metab. 2014, 25, 178-187. [CrossRef]

6. Oikawa, A.; Siragusa, M.; Quaini, F.; Mangialardi, G.; Katare, R.G.; Caporali, A.; van Buul, J.D.; van Alphen, F.P.J.; Graiani, G.; Spinetti, G.; et al. Diabetes mellitus induces bone marrow microangiopathy. Arterioscler. Thromb. Vasc. Biol. 2010, 30, 498-508. [CrossRef]

7. Fadini, G.P.; Ciciliot, S.; Albiero, M. Concise Review: Perspectives and Clinical Implications of Bone Marrow and Circulating Stem Cell Defects in Diabetes. Stem Cells 2017, 35, 106-116. [CrossRef]

8. Satterthwaite, A.B.; Burn, T.C.; Le Beau, M.M.; Tenen, D.G. Structure of the gene encoding CD34, a human hematopoietic stem cell antigen. Genomics 1992, 12, 788-794. [CrossRef]

9. Chotinantakul, K.; Leeanansaksiri, W. Hematopoietic stem cell development, niches, and signaling pathways. Bone Marrow Res. 2012, 2012, 270425. [CrossRef]

10. Gatti, R.A.; Meuwissen, H.J.; Allen, H.D.; Hong, R.; Good, R.A. Immunological reconstitution of sex-linked lymphopenic immunological deficiency. Lancet (Lond. Engl.) 1968, 2, 1366-1369. [CrossRef]

11. Casanova-Acebes, M.; Pitaval, C.; Weiss, L.A.; Nombela-Arrieta, C.; Chèvre, R.; A-González, N.; Kunisaki, Y.; Zhang, D.; van Rooijen, N.; Silberstein, L.E.; et al. Rhythmic modulation of the hematopoietic niche through neutrophil clearance. Cell 2013, 153, 1025-1035. [CrossRef] [PubMed]

12. Badami, C.D.; Livingston, D.H.; Sifri, Z.C.; Caputo, F.J.; Bonilla, L.; Mohr, A.M.; Deitch, E.A. Hematopoietic progenitor cells mobilize to the site of injury after trauma and hemorrhagic shock in rats. J. Trauma 2007, 63, 596-600. [CrossRef] [PubMed]

13. Dutta, P.; Sager, H.B.; Stengel, K.R.; Naxerova, K.; Courties, G.; Saez, B.; Silberstein, L.; Heidt, T.; Sebas, M.; Sun, Y.; et al. Myocardial Infarction Activates CCR2(+) Hematopoietic Stem and Progenitor Cells. Cell Stem Cell 2015, 16, 477-487. [CrossRef] [PubMed]

14. Porada, C.D.; Atala, A.J.; Almeida-Porada, G. The hematopoietic system in the context of regenerative medicine. Methods 2016, 99, 44-61. [CrossRef]

15. Asahara, T.; Murohara, T.; Sullivan, A.; Silver, M.; van der Zee, R.; Li, T.; Witzenbichler, B.; Schatteman, G.; Isner, J.M. Isolation of putative progenitor endothelial cells for angiogenesis. Science 1997, 275, 964-967. [CrossRef]

16. Steinmetz, M.; Nickenig, G.; Werner, N. Endothelial-regenerating cells: An expanding universe. Hypertension (Dallas, Tex. 1979) 2010, 55, 593-599. [CrossRef]

17. Basile, D.P.; Yoder, M.C. Circulating and tissue resident endothelial progenitor cells. J. Cell. Physiol. 2014, 229, 10-16. [CrossRef]

18. Medina, R.J.; Barber, C.L.; Sabatier, F.; Dignat-George, F.; Melero-Martin, J.M.; Khosrotehrani, K.; Ohneda, O.; Randi, A.M.; Chan, J.K.Y.; Yamaguchi, T.; et al. Endothelial Progenitors: A Consensus Statement on Nomenclature. Stem Cells Transl. Med. 2017, 6, 1316-1320. [CrossRef] 
19. Estes, M.L.; Mund, J.A.; Mead, L.E.; Prater, D.N.; Cai, S.; Wang, H.; Pollok, K.E.; Murphy, M.P.; An, C.S.T.; Srour, E.F.; et al. Application of polychromatic flow cytometry to identify novel subsets of circulating cells with angiogenic potential. Cytometry A 2010, 77, 831-839. [CrossRef]

20. Yoder, M.C.; Mead, L.E.; Prater, D.; Krier, T.R.; Mroueh, K.N.; Li, F.; Krasich, R.; Temm, C.J.; Prchal, J.T.; Ingram, D.A. Redefining endothelial progenitor cells via clonal analysis and hematopoietic stem/progenitor cell principals. Blood 2007, 109, 1801-1809. [CrossRef]

21. Medina, R.J.; O'Neill, C.L.; Sweeney, M.; Guduric-Fuchs, J.; Gardiner, T.A.; Simpson, D.A.; Stitt, A.W. Molecular analysis of endothelial progenitor cell (EPC) subtypes reveals two distinct cell populations with different identities. BMC Med. Genom. 2010, 3, 18. [CrossRef] [PubMed]

22. Setchenska, M.S.; Bonanou-Tzedaki, S.A.; Arnstein, H.R. Characteristic enzymatic changes during rabbit bone marrow erythroid cell development. Biomed. Biochim. Acta 1990, 49, S59-S63. [PubMed]

23. Purhonen, S.; Palm, J.; Rossi, D.; Kaskenpää, N.; Rajantie, I.; Ylä-Herttuala, S.; Alitalo, K.; Weissman, I.L.; Salven, P. Bone marrow-derived circulating endothelial precursors do not contribute to vascular endothelium and are not needed for tumor growth. Proc. Natl. Acad. Sci. USA 2008, 105, 6620-6625. [CrossRef] [PubMed]

24. Tasev, D.; Koolwijk, P.; van Hinsbergh, V.W.M. Therapeutic Potential of Human-Derived Endothelial Colony-Forming Cells in Animal Models. Tissue Eng. Part B Rev. 2016, 22, 371-382. [CrossRef] [PubMed]

25. Lin, Y.; Weisdorf, D.J.; Solovey, A.; Hebbel, R.P. Origins of circulating endothelial cells and endothelial outgrowth from blood. J. Clin. Investig. 2000, 105, 71-77. [CrossRef] [PubMed]

26. Ingram, D.A.; Mead, L.E.; Moore, D.B.; Woodard, W.; Fenoglio, A.; Yoder, M.C. Vessel wall-derived endothelial cells rapidly proliferate because they contain a complete hierarchy of endothelial progenitor cells. Blood 2005, 105, 2783-2786. [CrossRef]

27. Hubert, L.; Darbousset, R.; Panicot-Dubois, L.; Robert, S.; Sabatier, F.; Fallague, K.; Dignat-George, F.; Dubois, C. Neutrophils recruit and activate human endothelial colony-forming cells at the site of vessel injury via P-selectin glycoprotein ligand-1 and L-selectin. J. Thromb. Haemost. 2014, 12, 1170-1181. [CrossRef]

28. Yoder, M.C. Is endothelium the origin of endothelial progenitor cells? Arterioscler. Thromb. Vasc. Biol. 2010, 30, 1094-1103. [CrossRef]

29. Tura, O.; Skinner, E.M.; Barclay, G.R.; Samuel, K.; Gallagher, R.C.J.; Brittan, M.; Hadoke, P.W.F.; Newby, D.E.; Turner, M.L.; Mills, N.L. Late outgrowth endothelial cells resemble mature endothelial cells and are not derived from bone marrow. Stem Cells 2013, 31, 338-348. [CrossRef]

30. Thebaud, N.B.; Bareille, R.; Remy, M.; Bourget, C.; Daculsi, R.; Bordenave, L. Human progenitor-derived endothelial cells vs. venous endothelial cells for vascular tissue engineering: An in vitro study. J. Tissue Eng. Regen. Med. 2010, 4, 473-484. [CrossRef]

31. Rohde, E.; Bartmann, C.; Schallmoser, K.; Reinisch, A.; Lanzer, G.; Linkesch, W.; Guelly, C.; Strunk, D. Immune cells mimic the morphology of endothelial progenitor colonies in vitro. Stem Cells 2007, 25, 1746-1752. [CrossRef] [PubMed]

32. Yoder, M.C. Endothelial progenitor cell: A blood cell by many other names may serve similar functions. J. Mol. Med. 2013, 91, 285-295. [CrossRef] [PubMed]

33. Patel, R.S.; Li, Q.; Ghasemzadeh, N.; Eapen, D.J.; Moss, L.D.; Janjua, A.U.; Manocha, P.; Kassem, H.A.; Veledar, E.; Samady, H.; et al. Circulating CD34+ progenitor cells and risk of mortality in a population with coronary artery disease. Circ. Res. 2015, 116, 289-297. [CrossRef] [PubMed]

34. Maruyama, S.; Taguchi, A.; Iwashima, S.; Ozaki, T.; Yasuda, K.; Kikuchi-Taura, A.; Soma, T.; Ishii, H.; Murohara, T.; Takahashi, H.; et al. Low circulating CD34+ cell count is associated with poor prognosis in chronic hemodialysis patients. Kidney Int. 2008, 74, 1603-1609. [CrossRef] [PubMed]

35. Maler, J.M.; Spitzer, P.; Lewczuk, P.; Kornhuber, J.; Herrmann, M.; Wiltfang, J. Decreased circulating CD34+ stem cells in early Alzheimer's disease: Evidence for a deficient hematopoietic brain support? Mol. Psychiatry 2006, 11, 1113-1115. [CrossRef] [PubMed]

36. Taguchi, A.; Matsuyama, T.; Nakagomi, T.; Shimizu, Y.; Fukunaga, R.; Tatsumi, Y.; Yoshikawa, H.; Kikuchi-Taura, A.; Soma, T.; Moriwaki, H.; et al. Circulating CD34-positive cells provide a marker of vascular risk associated with cognitive impairment. J. Cereb. Blood Flow Metab. 2008, 28, 445-449. [CrossRef]

37. Orlic, D.; Kajstura, J.; Chimenti, S.; Bodine, D.M.; Leri, A.; Anversa, P. Bone marrow stem cells regenerate infarcted myocardium. Pediatr. Transplant. 2003, 7 (Suppl. 3), 86-88. [CrossRef] 
38. Yeh, E.T.H.; Zhang, S.; Wu, H.D.; Körbling, M.; Willerson, J.T.; Estrov, Z. Transdifferentiation of human peripheral blood CD34+-enriched cell population into cardiomyocytes, endothelial cells, and smooth muscle cells in vivo. Circulation 2003, 108, 2070-2073. [CrossRef]

39. Ishikawa, F.; Yasukawa, M.; Yoshida, S.; Nakamura, K.-I.; Nagatoshi, Y.; Kanemaru, T.; Shimoda, K.; Shimoda, S.; Miyamoto, T.; Okamura, J.; et al. Human cord blood- and bone marrow-derived CD34+ cells regenerate gastrointestinal epithelial cells. FASEB J. 2004, 18, 1958-1960. [CrossRef]

40. Thiele, J.; Varus, E.; Wickenhauser, C.; Kvasnicka, H.M.; Metz, K.A.; Beelen, D.W. Regeneration of heart muscle tissue: Quantification of chimeric cardiomyocytes and endothelial cells following transplantation. Histol. Histopathol. 2004, 19, 201-209. [CrossRef]

41. Gupta, S.; Verfaillie, C.; Chmielewski, D.; Kim, Y.; Rosenberg, M.E. A role for extrarenal cells in the regeneration following acute renal failure. Kidney Int. 2002, 62, 1285-1290. [CrossRef] [PubMed]

42. Jeevanantham, V.; Butler, M.; Saad, A.; Abdel-Latif, A.; Zuba-Surma, E.K.; Dawn, B. Adult bone marrow cell therapy improves survival and induces long-term improvement in cardiac parameters: A systematic review and meta-analysis. Circulation 2012, 126, 551-568. [CrossRef] [PubMed]

43. Fisher, S.A.; Dorée, C.; Brunskill, S.J.; Mathur, A.; Martin-Rendon, E. Bone Marrow Stem Cell Treatment for Ischemic Heart Disease in Patients with No Option of Revascularization: A Systematic Review and Meta-Analysis. PLoS ONE 2013, 8, e64669. [CrossRef]

44. Gao, W.; Chen, D.; Liu, G.; Ran, X. Autologous stem cell therapy for peripheral arterial disease: A systematic review and meta-analysis of randomized controlled trials. Stem Cell Res. Ther. 2019, 10, 140. [CrossRef] [PubMed]

45. Brownlee, M. The pathobiology of diabetic complications: A unifying mechanism. Diabetes 2005, 54, 1615-1625. [CrossRef] [PubMed]

46. Schaper, N.C.; Havekes, B. Diabetes: Impaired damage control. Diabetologia 2012, 55, 18-20. [CrossRef]

47. Rodrigues, M.; Wong, V.W.; Rennert, R.C.; Davis, C.R.; Longaker, M.T.; Gurtner, G.C. Progenitor cell dysfunctions underlie some diabetic complications. Am. J. Pathol. 2015, 185, 2607-2618. [CrossRef]

48. Tepper, O.M.; Galiano, R.D.; Capla, J.M.; Kalka, C.; Gagne, P.J.; Jacobowitz, G.R.; Levine, J.P.; Gurtner, G.C. Human endothelial progenitor cells from type II diabetics exhibit impaired proliferation, adhesion, and incorporation into vascular structures. Circulation 2002, 106, 2781-2786. [CrossRef]

49. Fadini, G.P.; Sartore, S.; Albiero, M.; Baesso, I.; Murphy, E.; Menegolo, M.; Grego, F.; Vigili de Kreutzenberg, S.; Tiengo, A.; Agostini, C.; et al. Number and function of endothelial progenitor cells as a marker of severity for diabetic vasculopathy. Arterioscler. Thromb. Vasc. Biol. 2006, 26, 2140-2146. [CrossRef]

50. Fadini, G.P.; Boscaro, E.; de Kreutzenberg, S.; Agostini, C.; Seeger, F.; Dimmeler, S.; Zeiher, A.; Tiengo, A.; Avogaro, A. Time course and mechanisms of circulating progenitor cell reduction in the natural history of type 2 diabetes. Diabetes Care 2010, 33, 1097-1102. [CrossRef]

51. Hörtenhuber, T.; Rami-Mehar, B.; Satler, M.; Nagl, K.; Höbaus, C.; Höllerl, F.; Koppensteiner, R.; Schernthaner, G.; Schober, E.; Schernthaner, G.-H. Endothelial progenitor cells are related to glycemic control in children with type 1 diabetes over time. Diabetes Care 2013, 36, 1647-1653. [CrossRef]

52. Palombo, C.; Kozakova, M.; Morizzo, C.; Gnesi, L.; Barsotti, M.C.; Spontoni, P.; Massart, F.; Salvi, P.; Balbarini, A.; Saggese, G.; et al. Circulating endothelial progenitor cells and large artery structure and function in young subjects with uncomplicated type 1 diabetes. Cardiovasc. Diabetol. 2011, 10, 88. [CrossRef]

53. Loomans, C.J.M.; de Koning, E.J.P.; Staal, F.J.T.; Rookmaaker, M.B.; Verseyden, C.; de Boer, H.C.; Verhaar, M.C.; Braam, B.; Rabelink, T.J.; van Zonneveld, A.-J. Endothelial progenitor cell dysfunction: A novel concept in the pathogenesis of vascular complications of type 1 diabetes. Diabetes 2004, 53, 195-199. [CrossRef]

54. Vasa, M.; Fichtlscherer, S.; Aicher, A.; Adler, K.; Urbich, C.; Martin, H.; Zeiher, A.M.; Dimmeler, S. Number and migratory activity of circulating endothelial progenitor cells inversely correlate with risk factors for coronary artery disease. Circ. Res. 2001, 89, E1-E7. [CrossRef]

55. Hill, J.M.; Zalos, G.; Halcox, J.P.J.; Schenke, W.H.; Waclawiw, M.A.; Quyyumi, A.A.; Finkel, T. Circulating endothelial progenitor cells, vascular function, and cardiovascular risk. N. Engl. J. Med. 2003, 348, 593-600. [CrossRef]

56. Schmidt-Lucke, C.; Rössig, L.; Fichtlscherer, S.; Vasa, M.; Britten, M.; Kämper, U.; Dimmeler, S.; Zeiher, A.M. Reduced number of circulating endothelial progenitor cells predicts future cardiovascular events: Proof of concept for the clinical importance of endogenous vascular repair. Circulation 2005, 111, 2981-2987. [CrossRef] 
57. Ghani, U.; Shuaib, A.; Salam, A.; Nasir, A.; Shuaib, U.; Jeerakathil, T.; Sher, F.; O’Rourke, F.; Nasser, A.M.; Schwindt, B.; et al. Endothelial progenitor cells during cerebrovascular disease. Stroke 2005, 36, 151-153. [CrossRef]

58. Rigato, M.; Avogaro, A.; Fadini, G.P. Levels of Circulating Progenitor Cells, Cardiovascular Outcomes and Death: A Meta-Analysis of Prospective Observational Studies. Circ. Res. 2016, 118, 1930-1939. [CrossRef]

59. Fadini, G.P.; Rigato, M.; Cappellari, R.; Bonora, B.M.; Avogaro, A. Long-term Prediction of Cardiovascular Outcomes by Circulating CD34+ and CD34+CD133+ Stem Cells in Patients With Type 2 Diabetes. Diabetes Care 2017, 40, 125-131. [CrossRef]

60. Rigato, M.; Fadini, G.P. Circulating Stem/Progenitor Cells as Prognostic Biomarkers in Macro- and Microvascular Disease: A Narrative Review of Prospective Observational Studies. Curr. Med. Chem. 2018, 25, 4507-4517. [CrossRef]

61. Wils, J.; Favre, J.; Bellien, J. Modulating putative endothelial progenitor cells for the treatment of endothelial dysfunction and cardiovascular complications in diabetes. Pharmacol. Ther. 2017, 170, 98-115. [CrossRef]

62. Mangialardi, G.; Oikawa, A.; Reni, C.; Madeddu, P. Bone Marrow Microenvironment: A Newly Recognized Target for Diabetes- Induced Cellular Damage. Endocr. Metab. Immune Disord. 2012, 12, 159-167. [CrossRef]

63. Al-Sharea, A.; Lee, M.K.S.; Purton, L.E.; Hawkins, E.D.; Murphy, A.J. The haematopoietic stem cell niche: A new player in cardiovascular disease? Cardiovasc. Res. 2019, 115, 277-291. [CrossRef]

64. Schofield, R. The relationship between the spleen colony-forming cell and the haemopoietic stem cell. Blood Cells 1978, 4, 7-25.

65. Liu, W.; Yu, F.; Zhou, Z.; Li, Y.-C.; Fan, D.; Zhu, K. Autologous Bone Marrow-Derived Stem Cells for Treating Diabetic Neuropathy in Metabolic Syndrome. Biomed Res. Int. 2017, 2017, 1-6. [CrossRef]

66. Cuminetti, V.; Arranz, L. Bone Marrow Adipocytes: The Enigmatic Components of the Hematopoietic Stem Cell Niche. J. Clin. Med. 2019, 8, 707. [CrossRef]

67. Santopaolo, M.; Sambataro, M.; Spinetti, G.; Madeddu, P. Bone marrow as a target and accomplice of vascular complications in diabetes. Diabetes Metab. Res. Rev. 2020, 36. [CrossRef]

68. Westerweel, P.E.; Teraa, M.; Rafii, S.; Jaspers, J.E.; White, I.A.; Hooper, A.T.; Doevendans, P.A.; Verhaar, M.C. Impaired Endothelial Progenitor Cell Mobilization and Dysfunctional Bone Marrow Stroma in Diabetes Mellitus. PLoS ONE 2013, 8, e60357. [CrossRef]

69. Kiel, M.J.; Morrison, S.J. Uncertainty in the niches that maintain haematopoietic stem cells. Nat. Rev. Immunol. 2008, 8, 290-301. [CrossRef]

70. Greenbaum, A.M.; Link, D.C. Mechanisms of G-CSF-mediated hematopoietic stem and progenitor mobilization. Leukemia 2011, 25, 211-217. [CrossRef]

71. Tay, J.; Levesque, J.-P.; Winkler, I.G. Cellular players of hematopoietic stem cell mobilization in the bone marrow niche. Int. J. Hematol. 2017, 105, 129-140. [CrossRef]

72. Arai, F.; Hirao, A.; Ohmura, M.; Sato, H.; Matsuoka, S.; Takubo, K.; Ito, K.; Koh, G.Y.; Suda, T. Tie2/Angiopoietin-1 Signaling Regulates Hematopoietic Stem Cell Quiescence in the Bone Marrow Niche. Cell 2004, 118, 149-161. [CrossRef]

73. Arai, F.; Yoshihara, H.; Hosokawa, K.; Nakamura, Y.; Gomei, Y.; Iwasaki, H.; Suda, T. Niche Regulation of Hematopoietic Stem Cells in the Endosteum. Ann. N. Y. Acad. Sci. 2009, 1176, 36-46. [CrossRef]

74. Papayannopoulou, T.; Nakamoto, B. Peripheralization of hemopoietic progenitors in primates treated with anti-VLA4 integrin. Proc. Natl. Acad. Sci. USA 1993, 90, 9374-9378. [CrossRef]

75. Weber, J.M.; Calvi, L.M. Notch signaling and the bone marrow hematopoietic stem cell niche. Bone 2010, 46, 281-285. [CrossRef]

76. Fadini, G.P.; Ferraro, F.; Quaini, F.; Asahara, T.; Madeddu, P. Concise Review: Diabetes, the Bone Marrow Niche, and Impaired Vascular Regeneration. Stem Cells Transl. Med. 2014, 3, 949-957. [CrossRef]

77. Lilly, A.J.; Johnson, W.E.; Bunce, C.M. The Haematopoietic Stem Cell Niche: New Insights into the Mechanisms Regulating Haematopoietic Stem Cell Behaviour. Stem Cells Int. 2011, 2011, 1-10. [CrossRef]

78. Méndez-Ferrer, S.; Michurina, T.V.; Ferraro, F.; Mazloom, A.R.; MacArthur, B.D.; Lira, S.A.; Scadden, D.T.; Ma'ayan, A.; Enikolopov, G.N.; Frenette, P.S. Mesenchymal and haematopoietic stem cells form a unique bone marrow niche. Nature 2010, 466, 829-834. [CrossRef]

79. Ding, L.; Saunders, T.L.; Enikolopov, G.; Morrison, S.J. Endothelial and perivascular cells maintain haematopoietic stem cells. Nature 2012, 481, 457-462. [CrossRef] 
80. May, M.; Slaughter, A.; Lucas, D. Dynamic Regulation of Hematopoietic Stem Cells by Bone Marrow Niches. Curr. Stem Cell Rep. 2018, 4, 201-208. [CrossRef]

81. Mangialardi, G.; Cordaro, A.; Madeddu, P. The bone marrow pericyte: An orchestrator of vascular niche. Regen. Med. 2016, 11, 883-895. [CrossRef] [PubMed]

82. Anthony, B.A.; Link, D.C. Regulation of hematopoietic stem cells by bone marrow stromal cells. Trends Immunol. 2014, 35, 32-37. [CrossRef] [PubMed]

83. Winkler, I.G.; Barbier, V.; Nowlan, B.; Jacobsen, R.N.; Forristal, C.E.; Patton, J.T.; Magnani, J.L.; Lévesque, J.-P. Vascular niche E-selectin regulates hematopoietic stem cell dormancy, self renewal and chemoresistance. Nat. Med. 2012, 18, 1651-1657. [CrossRef] [PubMed]

84. Greenbaum, A.; Hsu, Y.-M.S.; Day, R.B.; Schuettpelz, L.G.; Christopher, M.J.; Borgerding, J.N.; Nagasawa, T.; Link, D.C. CXCL12 in early mesenchymal progenitors is required for haematopoietic stem-cell maintenance. Nature 2013, 495, 227-230. [CrossRef]

85. Méndez-Ferrer, S.; Lucas, D.; Battista, M.; Frenette, P.S. Haematopoietic stem cell release is regulated by circadian oscillations. Nature 2008, 452, 442-447. [CrossRef]

86. Lucas, D.; Battista, M.; Shi, P.A.; Isola, L.; Frenette, P.S. Mobilized Hematopoietic Stem Cell Yield Depends on Species-Specific Circadian Timing. Cell Stem Cell 2008, 3, 364-366. [CrossRef]

87. Spiegel, A.; Shivtiel, S.; Kalinkovich, A.; Ludin, A.; Netzer, N.; Goichberg, P.; Azaria, Y.; Resnick, I.; Hardan, I.; Ben-Hur, H.; et al. Catecholaminergic neurotransmitters regulate migration and repopulation of immature human CD34+ cells through Wnt signaling. Nat. Immunol. 2007, 8, 1123-1131. [CrossRef]

88. Katayama, Y.; Battista, M.; Kao, W.-M.; Hidalgo, A.; Peired, A.J.; Thomas, S.A.; Frenette, P.S. Signals from the Sympathetic Nervous System Regulate Hematopoietic Stem Cell Egress from Bone Marrow. Cell 2006, 124, 407-421. [CrossRef]

89. Récalde, A.; Richart, A.; Guérin, C.; Cochain, C.; Zouggari, Y.; Yin, K.H.W.; Vilar, J.; Drouet, I.; Lévy, B.; Varoquaux, O.; et al. Sympathetic Nervous System Regulates Bone Marrow-Derived Cell Egress Through Endothelial Nitric Oxide Synthase Activation. Arterioscler. Thromb. Vasc. Biol. 2012, 32, 643-653. [CrossRef]

90. Howangyin, K.Y.; Silvestre, J.-S. Diabetes Mellitus and Ischemic Diseases. Arterioscler. Thromb. Vasc. Biol. 2014, 34, 1126-1135. [CrossRef]

91. Piccinin, M.A.; Khan, Z.A. Pathophysiological role of enhanced bone marrow adipogenesis in diabetic complications. Adipocyte 2014, 3, 263-272. [CrossRef]

92. Fadini, G.P.; Albiero, M.; Seeger, F.; Poncina, N.; Menegazzo, L.; Angelini, A.; Castellani, C.; Thiene, G.; Agostini, C.; Cappellari, R.; et al. Stem cell compartmentalization in diabetes and high cardiovascular risk reveals the role of DPP-4 in diabetic stem cell mobilopathy. Basic Res. Cardiol. 2013, 108, 313. [CrossRef]

93. Schatteman, G.C.; Hanlon, H.D.; Jiao, C.; Dodds, S.G.; Christy, B.A. Blood-derived angioblasts accelerate blood-flow restoration in diabetic mice. J. Clin. Investig. 2000, 106, 571-578. [CrossRef]

94. Egan, C.G.; Lavery, R.; Caporali, F.; Fondelli, C.; Laghi-Pasini, F.; Dotta, F.; Sorrentino, V. Generalised reduction of putative endothelial progenitors and CXCR4-positive peripheral blood cells in type 2 diabetes. Diabetologia 2008, 51, 1296-1305. [CrossRef]

95. Fadini, G.P.; Miorin, M.; Facco, M.; Bonamico, S.; Baesso, I.; Grego, F.; Menegolo, M.; de Kreutzenberg, S.V.; Tiengo, A.; Agostini, C.; et al. Circulating Endothelial Progenitor Cells Are Reduced in Peripheral Vascular Complications of Type 2 Diabetes Mellitus. J. Am. Coll. Cardiol. 2005, 45, 1449-1457. [CrossRef]

96. Ferraro, F.; Lymperi, S.; Mendez-Ferrer, S.; Saez, B.; Spencer, J.A.; Yeap, B.Y.; Masselli, E.; Graiani, G.; Prezioso, L.; Rizzini, E.L.; et al. Diabetes Impairs Hematopoietic Stem Cell Mobilization by Altering Niche Function. Sci. Transl. Med. 2011, 3, 104ra101. [CrossRef]

97. Tepper, O.M.; Carr, J.; Allen, R.J.; Chang, C.C.; Lin, C.D.; Tanaka, R.; Gupta, S.M.; Levine, J.P.; Saadeh, P.B.; Warren, S.M. Decreased Circulating Progenitor Cell Number and Failed Mechanisms of Stromal Cell-Derived Factor-1 $\alpha$ Mediated Bone Marrow Mobilization Impair Diabetic Tissue Repair. Diabetes 2010, 59, 1974-1983. [CrossRef] [PubMed]

98. Albiero, M.; Poncina, N.; Ciciliot, S.; Cappellari, R.; Menegazzo, L.; Ferraro, F.; Bolego, C.; Cignarella, A.; Avogaro, A.; Fadini, G.P. Bone Marrow Macrophages Contribute to Diabetic Stem Cell Mobilopathy by Producing Oncostatin M. Diabetes 2015, 64, 2957-2968. [CrossRef] [PubMed]

99. Albiero, M.; Ciciliot, S.; Tedesco, S.; Menegazzo, L.; D'Anna, M.; Scattolini, V.; Cappellari, R.; Zuccolotto, G.; Rosato, A.; Cignarella, A.; et al. Diabetes-Associated Myelopoiesis Drives Stem Cell Mobilopathy Through an OSM-p66Shc Signaling Pathway. Diabetes 2019, 68, 1303-1314. [CrossRef] [PubMed] 
100. Ceradini, D.J.; Kulkarni, A.R.; Callaghan, M.J.; Tepper, O.M.; Bastidas, N.; Kleinman, M.E.; Capla, J.M.; Galiano, R.D.; Levine, J.P.; Gurtner, G.C. Progenitor cell trafficking is regulated by hypoxic gradients through HIF-1 induction of SDF-1. Nat. Med. 2004, 10, 858-864. [CrossRef]

101. Shigeta, T.; Aoyama, M.; Bando, Y.K.; Monji, A.; Mitsui, T.; Takatsu, M.; Cheng, X.-W.; Okumura, T.; Hirashiki, A.; Nagata, K.; et al. Dipeptidyl Peptidase-4 Modulates Left Ventricular Dysfunction in Chronic Heart Failure via Angiogenesis-Dependent and -Independent Actions. Circulation 2012, 126, 1838-1851. [CrossRef]

102. Fadini, G.P.; Albiero, M.; Vigili de Kreutzenberg, S.; Boscaro, E.; Cappellari, R.; Marescotti, M.; Poncina, N.; Agostini, C.; Avogaro, A. Diabetes Impairs Stem Cell and Proangiogenic Cell Mobilization in Humans. Diabetes Care 2013, 36, 943-949. [CrossRef] [PubMed]

103. Proost, P.; Struyf, S.; Schols, D.; Durinx, C.; Wuyts, A.; Lenaerts, J.-P.; De Clercq, E.; De Meester, I.; Van Damme, J. Processing by CD26/dipeptidyl-peptidase IV reduces the chemotactic and anti-HIV-1 activity of stromal-cell-derived factor-1 $\alpha$. FEBS Lett. 1998, 432, 73-76. [CrossRef]

104. Fadini, G.P.; Boscaro, E.; Albiero, M.; Menegazzo, L.; Frison, V.; de Kreutzenberg, S.; Agostini, C.; Tiengo, A.; Avogaro, A. The Oral Dipeptidyl Peptidase-4 Inhibitor Sitagliptin Increases Circulating Endothelial Progenitor Cells in Patients With Type 2 Diabetes: Possible role of stromal-derived factor-1. Diabetes Care 2010, 33, 1607-1609. [CrossRef]

105. Thum, T.; Fraccarollo, D.; Schultheiss, M.; Froese, S.; Galuppo, P.; Widder, J.D.; Tsikas, D.; Ertl, G.; Bauersachs, J. Endothelial Nitric Oxide Synthase Uncoupling Impairs Endothelial Progenitor Cell Mobilization and Function in Diabetes. Diabetes 2007, 56, 666-674. [CrossRef] [PubMed]

106. Gallagher, K.A.; Liu, Z.-J.; Xiao, M.; Chen, H.; Goldstein, L.J.; Buerk, D.G.; Nedeau, A.; Thom, S.R.; Velazquez, O.C. Diabetic impairments in NO-mediated endothelial progenitor cell mobilization and homing are reversed by hyperoxia and SDF-1 $\alpha$. J. Clin. Investig. 2007, 117, 1249-1259. [CrossRef] [PubMed]

107. Hazra, S.; Jarajapu, Y.P.R.; Stepps, V.; Caballero, S.; Thinschmidt, J.S.; Sautina, L.; Bengtsson, N.; LiCalzi, S.; Dominguez, J.; Kern, T.S.; et al. Long-term type 1 diabetes influences haematopoietic stem cells by reducing vascular repair potential and increasing inflammatory monocyte generation in a murine model. Diabetologia 2013, 56, 644-653. [CrossRef]

108. Orlandi, A.; Chavakis, E.; Seeger, F.; Tjwa, M.; Zeiher, A.M.; Dimmeler, S. Long-term diabetes impairs repopulation of hematopoietic progenitor cells and dysregulates the cytokine expression in the bone marrow microenvironment in mice. Basic Res. Cardiol. 2010, 105, 703-712. [CrossRef]

109. Urabe, H.; Terashima, T.; Lin, F.; Kojima, H.; Chan, L. Bone marrow-derived TNF- $\alpha$ causes diabetic neuropathy in mice. Diabetologia 2015, 58, 402-410. [CrossRef]

110. Dang, Z.; Maselli, D.; Spinetti, G.; Sangalli, E.; Carnelli, F.; Rosa, F.; Seganfreddo, E.; Canal, F.; Furlan, A.; Paccagnella, A.; et al. Sensory neuropathy hampers nociception-mediated bone marrow stem cell release in mice and patients with diabetes. Diabetologia 2015, 58, 2653-2662. [CrossRef]

111. Dang, Z.; Avolio, E.; Albertario, A.; Sala-Newby, G.B.; Thomas, A.C.; Wang, N.; Emanueli, C.; Madeddu, P. Nerve growth factor gene therapy improves bone marrow sensory innervation and nociceptor-mediated stem cell release in a mouse model of type 1 diabetes with limb ischaemia. Diabetologia 2019, 62, 1297-1311. [CrossRef] [PubMed]

112. Albiero, M.; Poncina, N.; Tjwa, M.; Ciciliot, S.; Menegazzo, L.; Ceolotto, G.; Vigili de Kreutzenberg, S.; Moura, R.; Giorgio, M.; Pelicci, P.; et al. Diabetes Causes Bone Marrow Autonomic Neuropathy and Impairs Stem Cell Mobilization via Dysregulated p66Shc and Sirt1. Diabetes 2014, 63, 1353-1365. [CrossRef] [PubMed]

113. Lucas, D.; Bruns, I.; Battista, M.; Mendez-Ferrer, S.; Magnon, C.; Kunisaki, Y.; Frenette, P.S. Norepinephrine reuptake inhibition promotes mobilization in mice: Potential impact to rescue low stem cell yields. Blood 2012, 119, 3962-3965. [CrossRef] [PubMed]

114. Busik, J.V.; Tikhonenko, M.; Bhatwadekar, A.; Opreanu, M.; Yakubova, N.; Caballero, S.; Player, D.; Nakagawa, T.; Afzal, A.; Kielczewski, J.; et al. Diabetic retinopathy is associated with bone marrow neuropathy and a depressed peripheral clock. J. Exp. Med. 2009, 206, 2897-2906. [CrossRef]

115. Mangialardi, G.; Katare, R.; Oikawa, A.; Meloni, M.; Reni, C.; Emanueli, C.; Madeddu, P. Diabetes Causes Bone Marrow Endothelial Barrier Dysfunction by Activation of the RhoA-Rho-Associated Kinase Signaling Pathway. Arterioscler. Thromb. Vasc. Biol. 2013, 33, 555-564. [CrossRef]

116. Nishikawa, T.; Araki, E. Impact of Mitochondrial ROS Production in the Pathogenesis of Diabetes Mellitus and Its Complications. Antioxid. Redox Signal. 2007, 9, 343-353. [CrossRef] 
117. Klimova, T.; Chandel, N.S. Mitochondrial complex III regulates hypoxic activation of HIF. Cell Death Differ. 2008, 15, 660-666. [CrossRef]

118. Du, X.; Matsumura, T.; Edelstein, D.; Rossetti, L.; Zsengellér, Z.; Szabó, C.; Brownlee, M. Inhibition of GAPDH activity by poly(ADP-ribose) polymerase activates three major pathways of hyperglycemic damage in endothelial cells. J. Clin. Investig. 2003, 112, 1049-1057. [CrossRef]

119. Di Stefano, V.; Cencioni, C.; Zaccagnini, G.; Magenta, A.; Capogrossi, M.C.; Martelli, F. p66ShcA modulates oxidative stress and survival of endothelial progenitor cells in response to high glucose. Cardiovasc. Res. 2009, 82, 421-429. [CrossRef]

120. Vinci, M.C.; Piacentini, L.; Chiesa, M.; Saporiti, F.; Colombo, G.I.; Pesce, M. Inflammatory environment and oxidized LDL convert circulating human proangiogenic cells into functional antigen-presenting cells. J. Leukoc. Biol. 2015, 98, 409-421. [CrossRef]

121. Cesselli, D.; Beltrami, A.P.; Rigo, S.; Bergamin, N.; D’Aurizio, F.; Verardo, R.; Piazza, S.; Klaric, E.; Fanin, R.; Toffoletto, B.; et al. Multipotent progenitor cells are present in human peripheral blood. Circ. Res. 2009, 104, 1225-1234. [CrossRef] [PubMed]

122. Avitabile, D.; Magenta, A.; Lauri, A.; Gambini, E.; Spaltro, G.; Vinci, M.C. Metaboloepigenetics: The Emerging Network in Stem Cell Homeostasis Regulation. Curr. Stem Cell Res. Ther. 2016, 11, 352-369. [CrossRef] [PubMed]

123. Chacón-Martínez, C.A.; Koester, J.; Wickström, S.A. Signaling in the stem cell niche: Regulating cell fate, function and plasticity. Development 2018, 145. [CrossRef] [PubMed]

124. Kumar, A.H.S.; Metharom, P.; Schmeckpeper, J.; Weiss, S.; Martin, K.; Caplice, N.M. Bone marrow-derived CX3CR1 progenitors contribute to neointimal smooth muscle cells via fractalkine CX3CR1 interaction. FASEB J. 2010, 24, 81-92. [CrossRef]

125. Van Ark, J.; Moser, J.; Lexis, C.P.H.; Bekkema, F.; Pop, I.; van der Horst, I.C.C.; Zeebregts, C.J.; van Goor, H.; Wolffenbuttel, B.H.R.; Hillebrands, J.L. Type 2 diabetes mellitus is associated with an imbalance in circulating endothelial and smooth muscle progenitor cell numbers. Diabetologia 2012, 55, 2501-2512. [CrossRef] [PubMed]

126. Flammer, A.J.; Gössl, M.; Li, J.; Matsuo, Y.; Reriani, M.; Loeffler, D.; Simari, R.D.; Lerman, L.O.; Khosla, S.; Lerman, A. Patients with an $\mathrm{HbA} 1 \mathrm{c}$ in the prediabetic and diabetic range have higher numbers of circulating cells with osteogenic and endothelial progenitor cell markers. J. Clin. Endocrinol. Metab. 2012, 97, 4761-4768. [CrossRef]

127. Fadini, G.P.; Albiero, M.; Menegazzo, L.; Boscaro, E.; Agostini, C.; de Kreutzenberg, S.V.; Rattazzi, M.; Avogaro, A. Procalcific phenotypic drift of circulating progenitor cells in type 2 diabetes with coronary artery disease. Exp. Diabetes Res. 2012, 2012, 921685. [CrossRef]

128. Menegazzo, L.; Albiero, M.; Millioni, R.; Tolin, S.; Arrigoni, G.; Poncina, N.; Tessari, P.; Avogaro, A.; Fadini, G.P. Circulating myeloid calcifying cells have antiangiogenic activity via thrombospondin-1 overexpression. FASEB J. 2013, 27, 4355-4365. [CrossRef]

129. Nguyen, T.Q.; Chon, H.; van Nieuwenhoven, F.A.; Braam, B.; Verhaar, M.C.; Goldschmeding, R. Myofibroblast progenitor cells are increased in number in patients with type 1 diabetes and express less bone morphogenetic protein 6: A novel clue to adverse tissue remodelling? Diabetologia 2006, 49, 1039-1048. [CrossRef]

130. Yang, M.; Gan, H.; Shen, Q.; Tang, W.; Du, X.; Chen, D. Proinflammatory CD14+CD16+ monocytes are associated with microinflammation in patients with type 2 diabetes mellitus and diabetic nephropathy uremia. Inflammation 2012, 35, 388-396. [CrossRef]

131. Min, D.; Brooks, B.; Wong, J.; Salomon, R.; Bao, W.; Harrisberg, B.; Twigg, S.M.; Yue, D.K.; McLennan, S. $\mathrm{V}$ Alterations in monocyte CD16 in association with diabetes complications. Mediat. Inflamm. 2012, 2012, 649083. [CrossRef] [PubMed]

132. Cappellari, R.; D'Anna, M.; Bonora, B.M.; Rigato, M.; Cignarella, A.; Avogaro, A.; Fadini, G.P. Shift of monocyte subsets along their continuum predicts cardiovascular outcomes. Atherosclerosis 2017, 266, 95-102. [CrossRef] [PubMed]

133. Fadini, G.P.; Cappellari, R.; Mazzucato, M.; Agostini, C.; Vigili de Kreutzenberg, S.; Avogaro, A. Monocyte-macrophage polarization balance in pre-diabetic individuals. Acta Diabetol. 2013, 50, 977-982. [CrossRef] [PubMed] 
134. Lowe, G.; Woodward, M.; Hillis, G.; Rumley, A.; Li, Q.; Harrap, S.; Marre, M.; Hamet, P.; Patel, A.; Poulter, N.; et al. Circulating inflammatory markers and the risk of vascular complications and mortality in people with type 2 diabetes and cardiovascular disease or risk factors: The ADVANCE study. Diabetes 2014, 63, 1115-1123. [CrossRef]

135. Terenzi, D.C.; Al-Omran, M.; Quan, A.; Teoh, H.; Verma, S.; Hess, D.A. Circulating Pro-Vascular Progenitor Cell Depletion During Type 2 Diabetes: Translational Insights Into the Prevention of Ischemic Complications in Diabetes. JACC Basic Transl. Sci. 2019, 4, 98-112. [CrossRef]

136. Yang, J.; Zhang, L.; Yu, C.; Yang, X.-F.; Wang, H. Monocyte and macrophage differentiation: Circulation inflammatory monocyte as biomarker for inflammatory diseases. Biomark. Res. 2014, 2, 1. [CrossRef]

137. Fadini, G.P. A reappraisal of the role of circulating (progenitor) cells in the pathobiology of diabetic complications. Diabetologia 2014, 57, 4-15. [CrossRef]

138. Van Diepen, J.A.; Thiem, K.; Stienstra, R.; Riksen, N.P.; Tack, C.J.; Netea, M.G. Diabetes propels the risk for cardiovascular disease: Sweet monocytes becoming aggressive? Cell. Mol. Life Sci. 2016, 73, 4675-4684. [CrossRef]

139. Loomans, C.J.; van Haperen, R.; Duijs, J.M.; Verseyden, C.; de Crom, R.; Leenen, P.J.; Drexhage, H.A.; de Boer, H.C.; de Koning, E.J.; Rabelink, T.J.; et al. Differentiation of bone marrow-derived endothelial progenitor cells is shifted into a proinflammatory phenotype by hyperglycemia. Mol. Med. 2009, 15, 152-159. [CrossRef]

140. Nagareddy, P.R.; Murphy, A.J.; Stirzaker, R.A.; Hu, Y.; Yu, S.; Miller, R.G.; Ramkhelawon, B.; Distel, E.; Westerterp, M.; Huang, L.-S.; et al. Hyperglycemia promotes myelopoiesis and impairs the resolution of atherosclerosis. Cell Metab. 2013, 17, 695-708. [CrossRef]

141. Barman, P.K.; Urao, N.; Koh, T.J. Diabetes induces myeloid bias in bone marrow progenitors associated with enhanced wound macrophage accumulation and impaired healing. J. Pathol. 2019, 249, 435-446. [CrossRef] [PubMed]

142. Jaenisch, R.; Bird, A. Epigenetic regulation of gene expression: How the genome integrates intrinsic and environmental signals. Nat. Genet. 2003, 33 (Suppl. 3), 245-254. [CrossRef] [PubMed]

143. Ahmed, M.; de Winther, M.P.J.; Van den Bossche, J. Epigenetic mechanisms of macrophage activation in type 2 diabetes. Immunobiology 2017, 222, 937-943. [CrossRef] [PubMed]

144. Hanson, M.A.; Godfrey, K.M. Genetics: Epigenetic mechanisms underlying type 2 diabetes mellitus. Nat. Rev. Endocrinol. 2015, 11, 261-262. [CrossRef]

145. Vigorelli, V.; Resta, J.; Bianchessi, V.; Lauri, A.; Bassetti, B.; Agrifoglio, M.; Pesce, M.; Polvani, G.; Bonalumi, G.; Cavallotti, L.; et al. Abnormal DNA Methylation Induced by Hyperglycemia Reduces CXCR 4 Gene Expression in CD 34+ Stem Cells. J. Am. Heart Assoc. 2019, 8, e010012. [CrossRef]

146. Gallagher, K.A.; Joshi, A.; Carson, W.F.; Schaller, M.; Allen, R.; Mukerjee, S.; Kittan, N.; Feldman, E.L.; Henke, P.K.; Hogaboam, C.; et al. Epigenetic changes in bone marrow progenitor cells influence the inflammatory phenotype and alter wound healing in type 2 diabetes. Diabetes 2015, 64, 1420-1430. [CrossRef]

147. Bannon, P.; Wood, S.; Restivo, T.; Campbell, L.; Hardman, M.J.; Mace, K.A. Diabetes induces stable intrinsic changes to myeloid cells that contribute to chronic inflammation during wound healing in mice. Dis. Model. Mech. 2013, 6, 1434-1447. [CrossRef]

148. Yan, J.; Tie, G.; Wang, S.; Tutto, A.; DeMarco, N.; Khair, L.; Fazzio, T.G.; Messina, L.M. Diabetes impairs wound healing by Dnmt1-dependent dysregulation of hematopoietic stem cells differentiation towards macrophages. Nat. Commun. 2018, 9, 33. [CrossRef]

149. Fraineau, S.; Palii, C.G.; Allan, D.S.; Brand, M. Epigenetic regulation of endothelial-cell-mediated vascular repair. FEBS J. 2015, 282, 1605-1629. [CrossRef]

150. Costantino, S.; Libby, P.; Kishore, R.; Tardif, J.-C.; El-Osta, A.; Paneni, F. Epigenetics and precision medicine in cardiovascular patients: From basic concepts to the clinical arena. Eur. Heart J. 2018, 39, 4150-4158. [CrossRef]

151. Brandts, J.; Ray, K.K. Apabetalone-BET protein inhibition in cardiovascular disease and Type 2 diabetes. Future Cardiol. 2020. [CrossRef] [PubMed] 
152. Tsujikawa, L.M.; Fu, L.; Das, S.; Halliday, C.; Rakai, B.D.; Stotz, S.C.; Sarsons, C.D.; Gilham, D.; Daze, E.; Wasiak, S.; et al. Apabetalone (RVX-208) reduces vascular inflammation in vitro and in CVD patients by a BET-dependent epigenetic mechanism. Clin. Epigenet. 2019, 11, 102. [CrossRef] [PubMed]

153. Chan, C.H.; Fang, C.; Qiao, Y.; Yarilina, A.; Prinjha, R.K.; Ivashkiv, L.B. BET bromodomain inhibition suppresses transcriptional responses to cytokine-Jak-STAT signaling in a gene-specific manner in human monocytes. Eur. J. Immunol. 2015, 45, 287-297. [CrossRef] [PubMed]

154. 2. Classification and Diagnosis of Diabetes: Standards of Medical Care in Diabetes-2018. Diabetes Care 2018, 41, S13-S27. [CrossRef] [PubMed]

155. 9. Pharmacologic Approaches to Glycemic Treatment: Standards of Medical Care in Diabetes-2020. Diabetes Care 2020, 43, S98-S110. [CrossRef]

156. Cosentino, F.; Grant, P.J.; Aboyans, V.; Bailey, C.J.; Ceriello, A.; Delgado, V.; Federici, M.; Filippatos, G.; Grobbee, D.E.; Hansen, T.B.; et al. 2019 ESC Guidelines on diabetes, pre-diabetes, and cardiovascular diseases developed in collaboration with the EASD. Eur. Heart J. 2020, 41, 255-323. [CrossRef]

157. Liao, Y.; Chen, L.-L.; Zeng, T.; Li, Y.; Fan, Y.; Hu, L.; Ling, Y. Number of circulating endothelial progenitor cells as a marker of vascular endothelial function for type 2 diabetes. Vasc. Med. 2010, 15, 279-285. [CrossRef]

158. Chen, L.; Liao, Y.; Zeng, T.; Yu, F.; Li, H.; Feng, Y. Effects of metformin plus gliclazide compared with metformin alone on circulating endothelial progenitor cell in type 2 diabetic patients. Endocrine 2010, 38, 266-275. [CrossRef]

159. Wang, C.-H.; Ting, M.-K.; Verma, S.; Kuo, L.-T.; Yang, N.-I.; Hsieh, I.-C.; Wang, S.-Y.; Hung, A.; Cherng, W.-J. Pioglitazone increases the numbers and improves the functional capacity of endothelial progenitor cells in patients with diabetes mellitus. Am. Heart J. 2006, 152, 1051-e1. [CrossRef]

160. Werner, C.; Kamani, C.H.; Gensch, C.; Bohm, M.; Laufs, U. The Peroxisome Proliferator Activated ReceptorAgonist Pioglitazone Increases Number and Function of Endothelial Progenitor Cells in Patients With Coronary Artery Disease and Normal Glucose Tolerance. Diabetes 2007, 56, 2609-2615. [CrossRef]

161. Makino, H.; Okada, S.; Nagumo, A.; Sugisawa, T.; Miyamoto, Y.; Kishimoto, I.; Akie, T.K.; Soma, T.; Taguchi, A.; Yoshimasa, Y. Pioglitazone treatment stimulates circulating CD34-positive cells in type 2 diabetes patients. Diabetes Res. Clin. Pract. 2008, 81, 327-330. [CrossRef] [PubMed]

162. Esposito, K.; Maiorino, M.I.; Di Palo, C.; Gicchino, M.; Petrizzo, M.; Bellastella, G.; Saccomanno, F.; Giugliano, D. Effects of pioglitazone versus metformin on circulating endothelial microparticles and progenitor cells in patients with newly diagnosed type 2 diabetes-a randomized controlled trial. Diabetes Obes. Metab. 2011, 13, 439-445. [CrossRef] [PubMed]

163. Fidan, E.; Onder Ersoz, H.; Yilmaz, M.; Yilmaz, H.; Kocak, M.; Karahan, C.; Erem, C. The effects of rosiglitazone and metformin on inflammation and endothelial dysfunction in patients with type 2 diabetes mellitus. Acta Diabetol. 2011, 48, 297-302. [CrossRef] [PubMed]

164. Kampoli, A.-M.; Tousoulis, D.; Pallantza, Z.; Paterakis, G.; Papageorgiou, N.; Oikonomou, E.; Miliou, A.; Vlachopoulou, A.; Stefanadis, C. Comparable effects of pioglitazone and perindopril on circulating endothelial progenitor cells, inflammatory process and oxidative stress in patients with diabetes mellitus. Int. J. Cardiol. 2012, 157, 413-415. [CrossRef]

165. Genovese, S.; De Berardis, G.; Nicolucci, A.; Mannucci, E.; Evangelista, V.; Totani, L.; Pellegrini, F.; Ceriello, A. Effect of pioglitazone versus metformin on cardiovascular risk markers in type 2 diabetes. Adv. Ther. 2013, 30, 190-202. [CrossRef] [PubMed]

166. Vijay, S.K.; Mishra, M.; Kumar, H.; Tripathi, K. Effect of pioglitazone and rosiglitazone on mediators of endothelial dysfunction, markers of angiogenesis and inflammatory cytokines in type-2 diabetes. Acta Diabetol. 2009, 46, 27-33. [CrossRef]

167. Dore, F.J.; Domingues, C.C.; Ahmadi, N.; Kundu, N.; Kropotova, Y.; Houston, S.; Rouphael, C.; Mammadova, A.; Witkin, L.; Khiyami, A.; et al. The synergistic effects of saxagliptin and metformin on CD34+ endothelial progenitor cells in early type 2 diabetes patients: A randomized clinical trial. Cardiovasc. Diabetol. 2018, 17, 65. [CrossRef] 
168. Dei Cas, A.; Spigoni, V.; Cito, M.; Aldigeri, R.; Ridolfi, V.; Marchesi, E.; Marina, M.; Derlindati, E.; Aloe, R.; Bonadonna, R.C.; et al. Vildagliptin, but not glibenclamide, increases circulating endothelial progenitor cell number: A 12-month randomized controlled trial in patients with type 2 diabetes. Cardiovasc. Diabetol. 2017, 16, 27. [CrossRef]

169. Nakamura, K.; Oe, H.; Kihara, H.; Shimada, K.; Fukuda, S.; Watanabe, K.; Takagi, T.; Yunoki, K.; Miyoshi, T.; Hirata, K.; et al. DPP-4 inhibitor and alpha-glucosidase inhibitor equally improve endothelial function in patients with type 2 diabetes: EDGE study. Cardiovasc. Diabetol. 2014, 13, 110. [CrossRef]

170. Ayaori, M.; Iwakami, N.; Uto-Kondo, H.; Sato, H.; Sasaki, M.; Komatsu, T.; Iizuka, M.; Takiguchi, S.; Yakushiji, E.; Nakaya, K.; et al. Dipeptidyl Peptidase-4 Inhibitors Attenuate Endothelial Function as Evaluated by Flow-Mediated Vasodilatation in Type 2 Diabetic Patients. J. Am. Heart Assoc. 2013, 2. [CrossRef]

171. Morishita, T.; Uzui, H.; Ikeda, H.; Amaya, N.; Kaseno, K.; Ishida, K.; Fukuoka, Y.; Tada, H. Effects of Sitagliptin on the Coronary Flow Reserve, Circulating Endothelial Progenitor Cells and Stromal Cell-derived Factor-1alpha. Intern. Med. 2019, 58, 2773-2781. [CrossRef] [PubMed]

172. Widlansky, M.E.; Puppala, V.K.; Suboc, T.M.; Malik, M.; Branum, A.; Signorelli, K.; Wang, J.; Ying, R.; Tanner, M.J.; Tyagi, S. Impact of DPP-4 inhibition on acute and chronic endothelial function in humans with type 2 diabetes on background metformin therapy. Vasc. Med. 2017, 22, 189-196. [CrossRef] [PubMed]

173. Cosenso-Martin, L.N.; Giollo-Júnior, L.T.; Fernandes, L.A.B.; Cesarino, C.B.; Nakazone, M.A.; Machado, M. de N.; Yugar-Toledo, J.C.; Vilela-Martin, J.F. Effect of vildagliptin versus glibenclamide on endothelial function and arterial stiffness in patients with type 2 diabetes and hypertension: A randomized controlled trial. Acta Diabetol. 2018, 55, 1237-1245. [CrossRef] [PubMed]

174. Zheng, S.L.; Roddick, A.J.; Aghar-Jaffar, R.; Shun-Shin, M.J.; Francis, D.; Oliver, N.; Meeran, K. Association Between Use of Sodium-Glucose Cotransporter 2 Inhibitors, Glucagon-like Peptide 1 Agonists, and Dipeptidyl Peptidase 4 Inhibitors With All-Cause Mortality in Patients With Type 2 Diabetes. JAMA 2018, 319, 1580. [CrossRef] [PubMed]

175. Drucker, D.J. The Cardiovascular Biology of Glucagon-like Peptide-1. Cell Metab. 2016, 24, 15-30. [CrossRef]

176. Wei, R.; Ma, S.; Wang, C.; Ke, J.; Yang, J.; Li, W.; Liu, Y.; Hou, W.; Feng, X.; Wang, G.; et al. Exenatide exerts direct protective effects on endothelial cells through the AMPK/Akt/eNOS pathway in a GLP-1 receptor-dependent manner. Am. J. Physiol. Metab. 2016, 310, E947-E957. [CrossRef]

177. Hu, Y.; Liu, J.; Wang, G.; Xu, Y. The Effects of Exenatide and Metformin on Endothelial Function in Newly Diagnosed Type 2 Diabetes Mellitus Patients: A Case-Control Study. Diabetes Ther. 2018, 9, 1295-1305. [CrossRef]

178. Gurkan, E.; Tarkun, I.; Sahin, T.; Cetinarslan, B.; Canturk, Z. Evaluation of exenatide versus insulin glargine for the impact on endothelial functions and cardiovascular risk markers. Diabetes Res. Clin. Pract. 2014, 106, 567-575. [CrossRef]

179. Kelly, A.S.; Bergenstal, R.M.; Gonzalez-Campoy, J.; Katz, H.; Bank, A.J. Effects of Exenatide vs. Metformin on endothelial function in obese patients with pre-diabetes: A randomized trial. Cardiovasc. Diabetol. 2012, 11, 64. [CrossRef] [PubMed]

180. Nagaike, H.; Ohara, M.; Kohata, Y.; Hiromura, M.; Tomoyasu, M.; Takada, M.; Yamamoto, T.; Hayashi, T.; Fukui, T.; Hirano, T. Effect of Dulaglutide Versus Liraglutide on Glucose Variability, Oxidative Stress, and Endothelial Function in Type 2 Diabetes: A Prospective Study. Diabetes Ther. 2019, 10, 215-228. [CrossRef]

181. Nomoto, H.; Miyoshi, H.; Furumoto, T.; Oba, K.; Tsutsui, H.; Miyoshi, A.; Kondo, T.; Tsuchida, K.; Atsumi, T.; Manda, N.; et al. A Comparison of the Effects of the GLP-1 Analogue Liraglutide and Insulin Glargine on Endothelial Function and Metabolic Parameters: A Randomized, Controlled Trial Sapporo Athero-Incretin Study 2 (SAIS2). PLoS ONE 2015, 10, e0135854. [CrossRef] [PubMed]

182. Bonnet, F.; Scheen, A.J. Effects of SGLT2 inhibitors on systemic and tissue low-grade inflammation: The potential contribution to diabetes complications and cardiovascular disease. Diabetes Metab. 2018, 44, 457-464. [CrossRef] [PubMed]

183. Tentolouris, A.; Vlachakis, P.; Tzeravini, E.; Eleftheriadou, I.; Tentolouris, N. SGLT2 Inhibitors: A Review of Their Antidiabetic and Cardioprotective Effects. Int. J. Environ. Res. Public Health 2019, 16, 2965. [CrossRef] [PubMed] 
184. Shigiyama, F.; Kumashiro, N.; Miyagi, M.; Ikehara, K.; Kanda, E.; Uchino, H.; Hirose, T. Effectiveness of dapagliflozin on vascular endothelial function and glycemic control in patients with early-stage type 2 diabetes mellitus: DEFENCE study. Cardiovasc. Diabetol. 2017, 16, 84. [CrossRef] [PubMed]

185. Tanaka, A.; Shimabukuro, M.; Machii, N.; Teragawa, H.; Okada, Y.; Shima, K.R.; Takamura, T.; Taguchi, I.; Hisauchi, I.; Toyoda, S.; et al. Effect of Empagliflozin on Endothelial Function in Patients With Type 2 Diabetes and Cardiovascular Disease: Results from the Multicenter, Randomized, Placebo-Controlled, Double-Blind EMBLEM Trial. Diabetes Care 2019, 42, e159-e161. [CrossRef] [PubMed]

(C) 2020 by the authors. Licensee MDPI, Basel, Switzerland. This article is an open access article distributed under the terms and conditions of the Creative Commons Attribution (CC BY) license (http://creativecommons.org/licenses/by/4.0/). 